THE MUWASHSHAHATT* AND THE KHARJAS TELL THEIR OWN STORY

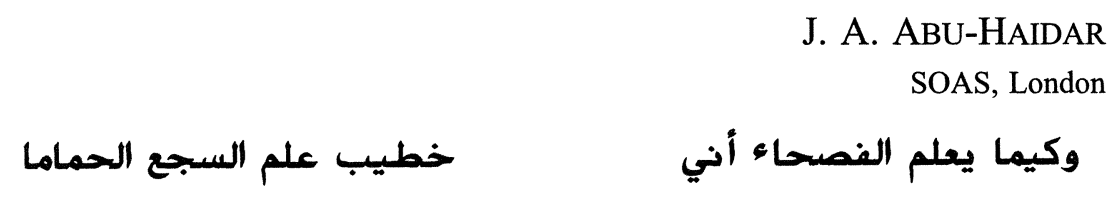

Those with pretensions to eloquence, should know that it is I who taught the use of rhymed prose, $s a j$ ' (lit. cooing) to the doves

Ibn Baqī

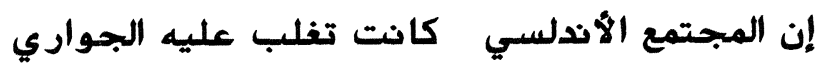

Andalusi society had a predominance of slave women

Ihsan Abbas

\title{
Introduction
}

It has always been my strong conviction that we have no normative treatise on the muwashshahät, and that the medieval literary historians and anthologists who made their scanty comments on them were in the same boat with us, inasmuch as they had to draw their conclusions from the available texts (Abu-Haidar: 2001: 47). The only treatise we possess on the muwashshahät are the muwashshahät themselves, and what their authors chance to tell us about them and about their seemingly intriguing kharjas, in the process of composing them. In keeping with all this, I shall not rehearse here what contemporary or near-contemporary authorities have had to tell us about the muwashshahạt, well-known authorities like Ibn Bassām (1069-1147), and Ibn Sanā' al-Mulk (1155-1211). I shall only quote the muwashshahāt themselves, and quote their composers in what they have to tell us about them. It could be that hearing the story from the horse's mouth in this way might help to eliminate the confusion and controversies which still attend the study of the muwashshahät and

\footnotetext{
* The Arabic plural, muwashshahāt, is used throughout this study to refer to the generic term, while the English plural muwashshahs, is used to refer to any number of separate compositions.
}

Al-Qanțara XXVI, 1 (2005) 43-98 
their kharjas. In trying to hear the evidence from the poets who wrote the muwashshahāt, I shall not only quote the foremost masters among them, poets like al-A'mā al-Tuṭilīi (d. 1126), Ibn Baqī (d. 1145), Ibn Zuhr (d. 1198) and Ibn Sahl (d. 1251), but I shall also quote the works of lesser or less known poets, and particularly from the earlier and experimental period.

In the light of all this, the present study, in four parts, constitutes an attempt to assess the raison d'être of the muwashshah and the kharja. I use "raison d'être» here in its literal sense, and that is the cause or «the justifying reason for the existence of something». It would readily be agreed that if we had known or been able to discern clearly the reason or purpose for the development of the muwashshah, and the purpose of the kharja tucked up at its end, then all the speculation about the origin of the first, and the role of the second would have become idle and expendable. Similarly perhaps, but on a level of much greater consequence, if we had known the reason for our existence, and on a single small globe in the wider spheres, then all the philosophical, religious, and scientific speculation of five or six thousand years about the origin or purpose of human life would also have been dispensable. We could then have dispensed even with Plato and the overriding culture that is ancient Greece.

\section{The Raison d'être of the Muwashshặ}

In the epigraph to this article Ibn Baqī (Yāqūt, vol. 6: 2821), ${ }^{1}$ in a gush of self-praise, fakhr, speaks of what he viewed as a mark of his supreme literary accomplishment. «Those with pretensions to literary control (lit. eloquence)», he says, «should know that it is I who taught rhymed prose, saj ' (lit. cooing) to the pigeons.» ${ }^{2}$ Thus, Ibn Baqi gives his readers to understand that a primary gauge of literary mas-

\footnotetext{
1 There have not been many compilers and literary critics in Arab history who are as sensitive and discerning in their literary tastes as Yāqūt al-Hamawī. R.A. Nicholson speaks of Yāquit's «great Geographical Dictionary». It is a tribute to Ibn Baqī, in my view, to quote his verses in the course of this discussion from Yāqūt's Mu'jam al-Udabä'.

${ }^{2}$ It should be pointed out for the benefit of non-Arabists that the term for rhymed prose in Arabic, $s a j$ ', means literally 'cooing', and the term is borrowed from the cooing of doves which is seen to be repetitive, and with a total accordance of cadence or sound, suggestive of perfect rhyme. Arabic, it should be remembered, is intolerant of imperfect rhymes.
} 
tery in his day and in his milieu was versatility in the use of rhymed prose.

It was back in 1945 that Robert Briffault, an ardent protagonist of Arabic influences on the Provençal troubadours, declared that «It was the Arabs who introduced rhyme into Europe» (1945: 28, and 1965: 33). Briffault, like other protagonists of literary theories, tended perhaps to speak in hyperboles. One can hear people in Europe retorting sharply that his statement sounds like saying that it was the Arabs who introduced singing or perhaps puns and popular sayings into Europe. Briffault would have been much nearer to the truth if he had said that «The Arabs in al-Andalus introduced rhymed prose into their literary writings as early as the ninth century, and went on to cultivate more elaborate and prolific rhyme both in their prose writings and in their poetry» (Nicholson: 327-328 and Abu-Haidar, 2001: 121-122).

Ibn Baqi is not known to us as a prose writer, but primarily as a poet in the traditional style, and as a muwashshah composer, washshäh, of the first calibre. When he prides himself on «teaching rhymed prose to the very pigeons» he is priding himself on introducing prolific rhyme into poetry, and, in his case of course, into his muwashshah compositions. The raison d'être of the muwashshahät is introducing prolific rhyme, saj', in Arabic prose into Arabic poetry. The Arab literati did not set out in al-Andalus to write strophic poetry. In that case they would have called the new form shi ' $r$ maqta ' $i$, strophic or stanzaic poetry, or continued perhaps to use the terms shi $r$ musammat or qașä'id musammața. They set out to adorn poetry with added rhyme, which had been traditionally esteemed as a prized form of literary 'adornment' or 'embellishment', and hence the name muwashshahät, the 'adorned' or 'embellished' poems given to the new compositions.

A literature can tell its story better than those who have written about it in the past or in the present. There are those who still tell us that the Andalusi poets wrote muwashshahs because they found Romance prototypes in al-Andalus on which to model the new poetry. Ibn Baqi tells us that the Andalusi poets wrote muwashshaḩs in order to give $s a j$ ', or rhyme, a free range when writing poetry. No chicken and egg puzzle can arise in the case of the muwashshah either. Profuse $s a j$ ' came first, and the muwashshah followed. Contrary to the various surmises about the appearance or the date of the 
first muwashshahs, the new form must have made its appearance at the beginning of the eleventh century when the Umayyad Caliphate in al-Andalus started to be dismembered. The muwashshah in Arabic poetry was a development waiting to happen. It did not happen in the Arab East because the authority of the Caliphate in the East continued to make itself felt and did not allow for the literary tradition to be flouted. Al-Andalus was the most far-flung province of the Arab Empire, and the hegemonic reigns of 'Abd al-Rahmān III (912-961) and al-Hakam II (961-976), were well-nigh forgotten at the beginning of the eleventh century. "When the cat is away the mice do play» is a saying which operates on the literary level also. Without a strong central authority and central court, poets felt free to flout the tradition. They did not only write a poetry festooned with rhyme, but they went on to end some of their new compositions with audaciously saucy couplets in Romance or mixed Arabic and Romance. What is more, a good many of these audacious couplets, whether in Arabic or Romance, seem, as we shall see below, ${ }^{3}$ to have proceeded from or were picked up at the taverns of the day.

With the wide currency and popularity of rhyme in Arabic letters at the time, the new form of poetry was not to be shunned or shrugged off. Those among the contemporary Arab literati who seemed on the face of it to shrug it off were well aware of their ambivalent attitude, and revealed as much. ${ }^{4}$ Nor did the new form constitute much of a feat or a tour de force in the context of Arabic letters. The term for rhyme in the traditional Arabic qasida, qäfiya, has two denotations 'end' and 'end-rhyme'. All that a poet like Ibn Mā' al-Samā' (d. 1028 or 1031) needed to do, if he is the originator of the muwashshah form, was to use the qafiya, or end-rhyme, in an initial position also, and thus start a free-for-all contest or exercise in espousing and developing a new form of poetry. Ibn Mā' al-Samā' wrote as the matla' of one of the earliest muwashshahs (Ghazi, I: 5):

\footnotetext{
${ }^{3}$ See the sections on the kharja below.

${ }^{4}$ For comments on the ambivalent attitudes of Ibn Bassām, and the historian of the Almohad dynasty 'Abd al-Wāhid al-Marrākushī towards the muwashshạ see Abu-Haidar, 2001: 136 and 141 respectively.
} 
Man wali
Yu'dhali
'He who holds sway
Will be severely censured fi ummatin amran wa-lam ya'dili illä lihāza 'l-rasha'i 'l-akhali ${ }^{5}$ over any matter of state and does not act with justice, but the glances of the dark-eyed fawn escape all censure'.

Once the end-rhyme was successfully used as an initial rhyme also, an equally felicitous exercise would have readily followed, and that is the introduction of medial or internal rhymes into verses. This, of course, entailed breaking the traditional verse into segments with rhymes at the end of each segment. Scholars who still puzzle over Ibn Bassām's statement as to how the first washshāh went about writing his compositions (Ibn Bassām, Part I, vol. 1: 469), have paid little heed to his remark that the first washshäh based his compositions on ashtär al-ash'är, or hemistichs of poetry. In the context of the muwashshah this does not only refer to the traditional hemistichs of equal length and quantitative value, but also to the new segments of varying length with rhyme words at the end of each of them.

If all this should seem speculative, what is not speculative is that initial and multiple interlinear rhymes, together with an end rhyme in a line of verse, were not a Romance influence on the development of the muwashshah. For those also who still insist on tracing Andalusi Arabic influences on the verse forms of the Provençal troubadours, ${ }^{6}$ initial and interlinear rhymes do not anywhere appear as a feature of the Provençal strophe.

But the new form of poetry, the 'adorned' or 'embellished', the muwashshah, was not to be adorned only with added rhyme. Ibn Baqi prides himself on another important aspect of what could well be called his literary formation. In another verse of his traditional poetry (Yāqūt, vol. 6: 2821) he declares, and again with consummate pride:

Salaktu asālība 'l-badī'i fa-asbahat

Bi-aqwāl-iya 'l-rukbānu fi-'l-bìdi tartamì

\footnotetext{
5 It should be pointed out for interested readers, that in fairly recent times the Syro-American poet Rashid Ayyub (1872-1941) wrote a most fascinating and touching poem apparently modelled on this muwashshah of Ibn Mā' al-Samā'. See his collection Aghānī al-Darwīsh, Beirut, 1959: 68-72.

6 See a fairly recent attempt to do this by G. Schoeler in Corriente, F. and SaénzBadillos, A. (eds.), Poesía Estrófica, Madrid 1991: 325-335.
} 


\footnotetext{
'I have followed the badi styles of writing (i.e. decked with novel and striking tropes), so that travellers upon camels and horses in the desert, vie with each other in repeating my verses (lit. what I say).'
}

Whether Ibn Baqi was referring in this latter verse to «the novel and striking tropes», much popularized by such Abbasid poets like Abū Tammām (d. 846) in the Arab East, and referred to collectively as $b a d \imath$, or whether he was referring to Badī' al-Zamān al-Hamadhānī (d. 1007) (known also as al-Badī') who perpetuated the use of these tropes, together with rhymed prose, in his maqāmatt, is immaterial for the purposes of the present discussion. What matters here is that neither Ibn Baqi, nor any of his contemporaries among the Andalusi poets refer to, or pride themselves on Romance influences on their work, or acculturation of any form they might have had in Romance. They pride themselves on what hailed from the Arab East, the use of $s a j$ ' and $b a d \tau^{`}$, which went hand in hand with each other. Amazingly enough too, the people, the audiences Ibn Baqi wanted to impress with what he wrote, were travellers upon camels and horses in the bid, the Arabian deserts. Nearly two and a half centuries after Ibn Baqī, Ibn al-Khatīb, in his introductory notes on Ibn Labbūn, in Jaysh al-Tawshị (195), describes the poet's compositions as a lujjatun bi-'l-badi' $i$ tatfah 'a deep sea overflowing with $b a d i^{\prime}$ '.

There is still more to our story, however, than all this. Ibn Baqi is the author of what is perhaps the most tender love verses in the whole history of Arabic literature (Yãqūt, 1993, vol. 6: 2822). Adolescents learn these verses by heart, and recite them with a gush of blatant emotion. Scholars invariably reach for their pens and copy them out when they come across them. The verses in question come to a peak with the poet describing how his beloved fell asleep one night while embracing him, and with her head resting on his chest. As the ribs in Arabic are taken as the seat of the tender emotions, the poet then tells his readers how, in spite of himself, he had to move his beloved's head off his chest (lit. his ribs) so that she does not rest it on a palpitating pillow, 'alā wisädin khäfiqi:

$$
\begin{aligned}
& \text { Ab'adtuhu 'an aḍlu'in tashtāqu-hu } \\
& \text { kay lā yanāma 'alā wisādin khāfiqi. }
\end{aligned}
$$

It is a touching story. But, for our immediate purpose, the rendez-vous of the poet and his beloved is of greater significance. He 
does not meet her anywhere in al-Andalus, not by, or on a leafy and secluded bend of a wäd like the Guadalquivir, which Ibn Baqi would have known and loved. ${ }^{7} \mathrm{He}$ meets his beloved, typically referred to in pre-Islamic style as a gazelle, ${ }^{8}$ in a place between al-'Udhayb and Bāriq, two place names in the Arab East immortalized in an opening verse of an ode by the Eastern Arab poet al-Mutanabbī (d. 965) (Dīwān: 393).

This attitude of Ibn Baqī, traced here in his traditional poetry, epitomizes the attitude of practically all Andalusi poets, but particularly all poets who composed muwashshahāt in al-Andalus in his day, and in the century that followed. Their focus was on rhyme, on a wide gamut of literary tropes, or $b a d \bar{l}^{-}$, and on the fauna and flora of pre-Islamic Arabic poetry, and quite often its toponymy as well. Arabic poetry in al-Andalus, both in the traditional and muwashshah forms often evokes a nostalgia for lands (or merely place names) in Arabia or the Arab East in general which the poets had never seen. Only pilgrims, perhaps, have a similar nostalgia for holy cities they have never seen.

Was al-A'mā al-Tutịili 'The Blind Poet of Tudela', the contemporary and peer of Ibn Baqi any more accultured in Romance than Ibn Baqī was? He was not. The great poet and wit Abū Nuwās is reputed to have described the philologist Abū 'Ubayda (d.c. 825) as «a skin stuffed with knowledge» (Gibb: 54). Anyone who reads the diw $\bar{a} n$ of al-A 'mā al-Tutịili in its entirety (both muwashshah compositions, and often lengthy qasidas), will come to the conclusion that the poet was «a skin stuffed with classical Arabic literature and Arab lore». The verses and half-verses from pre-Islamic and Abbasid poetry he adapts or simply incorporates into his qasidas are too many to be enumerated. This is particularly true of the poetry of the blind sage of the Arab East al-Ma'arrī (979-1057) whose works must have held an

${ }^{7}$ I am largely basing this remark on muwashshah no. 12 by the poet (Ghazi, I: 444-446) where he exclaims in a highly buoyant mood in the kharja, that getting drunk on the banks of a wäd is worth all the wealth of Iraq (this, of course, referred to the heyday of the Abbasid Caliphate in Baghdad). While the muwashshah in question is described by Ibn Sa'īd in Al-Mughrib as "one of the famous muwashshahs» of Ibn Baqī, it is attributed by Ibn al-Khatịib in Jaysh al-Tawshịh to al-A'mā al-Tutilì.

${ }^{8}$ It is, of course, very much open to question, as we shall see when discussing the poet's muwashshahs, whether the poet in all this is referring to a male or female companion. But this has no bearing at all on the present argument. 
added appeal for the Blind Poet of Tudela (Diwwān: 80, 94, 145 and 150, n. 1).

The non-Arabist can gauge the sway that Arabic literature in the East exercised among the literati in al-Andalus from the following two half-verses:

1. Awaddu mina 'l-ayyāmi mã lä tawaddu-hu

and 2. Ashä'u mina 'l-ayyāmi mā lä tashā'u-hu

Both half-verses complain of the indifference with which life seems to treat our aspirations, and both say practically literally:

'I wish to achieve in life that which life has no wish to let me achieve'.

The first of them is from the opening verse of an ode by al-Mutanabbi (Dïwän: 453), and the second is from a short piece by al-A 'mā al-Tuṭilī (Dīwān: 79) in which al-Mutanabbī's tuning fork can hardly be missed or disguised.

If all this is to show or to claim that two of the top muwashshah composers in al-Andalus do not seem to have had any schooling in Romance, how is it, it would be asked, that each of them uses no less than four or five Romance kharjas in his muwashshahs. But the Romance kharjas, as the following parts of this study will try to show, were, in the large majority of them, adjuncts or appendages in the muwashshahs in which they appear, and not an integral part of them. They were meant to show technical skill, or one might say technical "wizardry» in attaching couplets in Romance to highly elaborate Arabic poems. More important, as we shall see, they had even less of a connection with the muwashshah when they were declaimed in a woman's voice whether in Arabic or Romance. As these latter kharjas constitute, almost invariably, an abrupt shift to a woman's or slave-woman's voice, they were often meant, it would seem, to introduce an element of titillation or perhaps explicit pornography for audiences who did not as yet have the «benefits» of present-day films or videos.

Apart from Ibn Baqī and al-A 'mā al-Tuṭilīi, however, I mentioned above two other poets who are grouped with them as the leading muwashshah composers, Ibn Zuhr and Ibn Sahl. Ibn Zuhr is arguably the author of one of the most admirable and admired muwashshahs, Ayyuhā 'l-sāqi ilay-ka 'l-mushtakā 'Cupbearer, it is to you that we 
come with our grievances', a wine and love song combined into one (Ghazi, II: 76-78). This muwashshah with a few others by Ibn Zuhr are among the best examples we have got of how lyrical any language can be in the hands of a good poet. In the same way, Ibn Sahl is unquestionably the foremost master in introducing sharp and brilliant kharjas into his equally brilliant muwashshahs, with a wit that is both admirable and instructive. He was, we are told, a convert to Islam from Judaism. But no poet displays, albeit within his poetry, a wider and deeper knowledge of the Sharia and the Qur'anic texts. And he puts his knowledge of the Sharia to good use in one of the most brilliant kharjas that we have, but with the utmost probity and propriety (Hal darã zabyu 'l-himā, muwashshah no. 1, Ghazi, II: 182-185). ${ }^{9}$

But neither of these two latter masters indulged the whim of using Romance kharjas in their poetry. Neither of them resorted to the vulgar or the smutty in order to achieve effect. Just as Ibn Sahl dignifies classical Arabic with his sharp wit, Ibn Zuhr confers grace on the colloquial wherever it appears in his kharjas. The works of both of these poets fly in the face of what Ibn Bassām said about the genesis of the muwashshah and its being built on colloquial or Romance foundations. The grace of the kharjas in their works flies in the face too of what Ibn Sanā' al-Mulk stipulated for the kharja, of piquancy or salaciousness, and the way he went on to illustrate it in his own muwashshahs (Rikabi: 119-185). The muwashshahs of a master like Ibn Sahl went on to be imitated for centuries after his death, and, among others, by one of the most prominent literati of al-Andalus, Ibn al-Khațîb (d. 1374) (Ghazi, II: 484-488).

\section{The Raison d'être of the Kharja}

As in the preceding discussion, it is the poets themselves, the muwashshah composers and their texts which will be our primary

\footnotetext{
${ }^{9}$ As the Qur'anic text (sura, viii, 41) stipulates that a fifth of all booty in times of war reverts to the State to be used for the common good, Ibn Sahl pleads with his beloved in the kharja to the muwashshah in question: Ayyuhā 'l-äkhidhu qalbì maghnamā Ij'ali 'l-wasla makāna 'l-khumusi 'You who have taken away my heart as booty, can't you allow for union (with me) to stand for the fifth (due to the State)!'
} 
guide for understanding the role, or the so-called enigma of the kharja.

In a probing assessment of scholarship on the Romance kharjas up to the mid-1980s, Alan Deyermond (72) asks the question as to whether the kharjas are woman's song, and immediately adds: «If the question is asked about the kharjas in general, no firm answer is possible: the variety is too great». The kharja could in fact well say: «my name is Legion.» But what can perhaps best describe the unpredictable and wanton forms it can take is the Lebanese popular saying min $k u l l w \bar{a} d \bar{l}$ 'as $\bar{a}$ 'a different stick from each and every vale'. While the present discussion will deal with the kharja, so to speak, as a generic term applying to all kharjas in this motley variety, the third section in this study will concentrate largely on what could best be described as the woman's-voice kharjas, or simply those kharjas declaimed by women whether they be in Arabic or Romance or mixed Arabic and Romance.

The Kharja is a Sally of Wit (Arabic: zarf)

In the large majority of his muwashshahs, Muhammad ibn 'Ubāda al-Qazzāz, the court poet and panegyrist of al-Mu'tașim ibn Șumādih, and his sons, rulers of Almería, used classical Arabic in the kharjas, as was befitting in muwashshahs of praise, and lauding the military prowess of his patrons. But one of these panegyrics, he was able to, or found it fit to end on a lighter note, with the following final strophe and kharja, which he seems to declaim in person (Ghazi, I: 168): ${ }^{10}$

$$
\begin{aligned}
& \text { Lammā șadar-tu 'an mawqifi 'l-zahfi } \\
& \text { Ghāzal-tu shādinan jā'ira 'l-țarfi } \\
& \text { Wa-qultu tābi an sunnata 'l-zarfi } \\
& \text { Bi 'l-hawma }{ }^{11} \text { yã rashā man saqā 'l-rāh }
\end{aligned}
$$

${ }^{10}$ In Jaysh al-Tawshih this muwashshah is attributed to al-Abyad (Jaysh: 60-61) The published texts do not give any clear indication as to who is declaiming the kharja. The crucial vowel signs which indicate that are not provided. It should be pointed out here that it is immaterial for the purposes of this discussion as to which of the two poets concerned future research might confirm the attribution of the muwashshah in question.

${ }^{11}$ In Jaysh al-Tawshịh this term appears as bi 'l-hurma which is a more apposite and likely reading. See, however Ghazi, I: 489 and Ghazi, II: 637. Muwashshah no. 223 in 'Udda: 336 , clearly has hurma in its kharja. 
'aynayk 'l-mlāh

'When I left the field of battle,

I dallied with a young fawn whose eyes can be unkind

And I said following the customary practice of zarf (of wittiness):

In the thick of the fray, young fawn, who served with wine your charming eyes? ${ }^{12}$

The poet clearly refers to the introduction of a light-hearted, vivacious couplet at the end of his muwashshah as a sunna, a customary practice, or, to give it its full name, sunnat al-zarf, the practice of ending the muwashshah on a note of wittiness. But while the zarf or wittiness in this case is introduced in a familiar everyday jargon, or vernacular Arabic, it could well be claimed that one of the most graceful kharjas of all time is in classical Arabic, and it is no wonder that the kharja in question appears in a muwashshah variously attributed to one or the other of the two most prominent poets at the turn of the eleventh century, al-A'mā al-Tutịilì and Ibn Baqī (Ghazi, I: 435-437; Abbas, 1963: 267-268; Rikabi: 63-64). The poet in this case (be it Ibn Baqī or al-A'mā al-Tuṭilī) is drinking among a group of boon companions. What is significant for our purpose is that he refers to his companions endearingly as halbat al-zarf 13 'the arena or circle of master wits'. While Ibn Sahl, discussed above (Part I), evokes Sharia law in introducing one of his brilliant kharjas, the poet here evokes early Islamic history when many of the believers

12 In his work on the kharjas, Otto Zwartjes (216) reading bi 'l-hurma, gives this kharja a puzzling translation: 'By the sacredness, gazelle, who poured wine before your sweet eyes?'. On the same page (216, n. 55), he seems to misread another kharja he quotes ('Udda: no. 294), and gives an equally puzzling text and translation. The kharja in question reads:

$$
\text { al-ghazāl hazz 'l-watar wa 'l l-ku'ūsu tutra'u }
$$

Reading wabar 'fur' or 'soft hair' instead of watar 'string' or 'chord' of a lute, or other musical instruments, he translates:

'The gazelle shakes her hair, while cups are being poured'.

It should be pointed out also that Zwartjes often fails to verify the translations of kharjas made by other scholars before him. One example of this is the way he accepts the Arabic metaphor for a slender and supple stature, $y \bar{a}$ ' $\bar{u} d$ al-zān 'oh (supple) bough of a beech tree' as being a reference to a lute (Ar. 'úd) made out of oak wood. The translation he quotes for $y \bar{a}$ ' 'ud azzān (his transliteration) is 'oak wooden lute' (217). Zwartjes goes on to quote the first couplet of the kharja in question in full $(219, \mathrm{n} .58)$ " $y \bar{a}$ ' 'úd azzn qum $\bar{a} ' i d n \bar{l}$ (sic)", and quotes the translation: 'Oh lute [made of] oak-wood, come and help me!' (See Abu-Haidar, 2001: 183 and 229, n.3).

${ }_{13}$ The early Abbasid poet Abū Nuwās (371) speaks of halbat al-lahw 'the circle of pleasure seekers'. 
turned apostate (irtaddū) immediately after the death of the Prophet. He says:

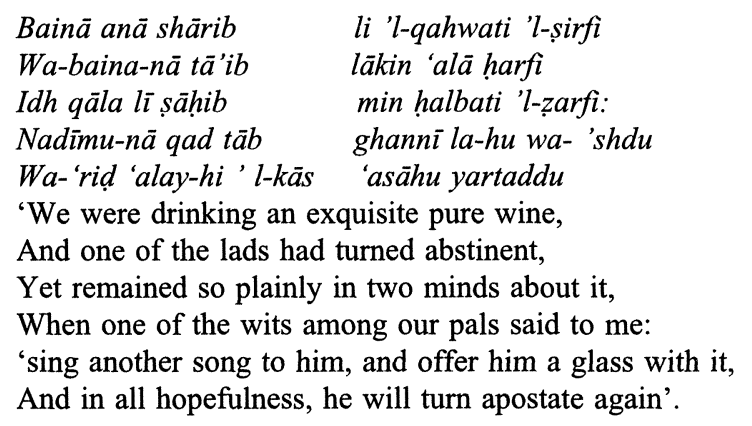

Ibn al-Qazzāz already refers to the introduction of a witty or facetious couplet, or a savour of zarf at the end of a muwashshah as a Sunna, or an established practice. Ibn Baqi refers to his boon companions as 'the circle' or 'arena' of wits, halbati 'l-zarfi. He explicitly tells us too that it is a member of this 'circle of wits' who improvises the clever and waggish couplet at the end of his muwashshah examined above. Like Ibn al-Qazzāz, al-A'mā al-Tutīilī also refers to zarf as a Sunna. Hubbu 'l-milähi fardun, wa-bāqi 'l-zarfi sunna, he decrees (Ghazi, I: 292 and Rikabi: 112), 'The love of beautiful women is a divine ordinance, while the rest [of the prescriptions] of zarf are customary practices which do not constitute divine orders'.

It is clear from all this that zarf 'wit' or 'wittiness' was very much on the minds of the Andalusi poets who wrote muwashshahs. As it was their practice to save the wittiness for the last, or, one might say, the bowing out couplets of their compositions, i.e. the kharjas, defining the kharja as 'a sally of wit' or an element of zarf, ${ }^{14}$ seems apt and to the point.

14 The term kharja implying a shift or a transition from one subject or theme to another, or from one mode of writing to another, in this case from the studiedly classical (in the main body of the muwashshah) to the hazl, the waggish or the popular, would be familiar to students of classical Arabic literature from its close association with the technical term $k h u r u ̈ j$ or takhallus. The latter terms, of course, referred to affecting a deft transition from one theme to another in classical Arabic poetry (see on khurüj, e.g. Ibn Rashīq, I: $388,412,415-416$ ). Those scholars who still try to understand the role of the kharja through a semantic analysis of cognate terms it could possibly derive from (such as the fourth form of the verb akhraja, instead of the ground root kharaja), seem to be unaware that, in keeping with the logic of the Arabic derivative system, if the opening couplet or 
The rest of this discussion on the kharja as a sally of zarf or wittiness will be a brief survey of the history of zarf in classical Arabic literature before it became enshrined as a Sunna in the kharja of the muwashshah.

\section{Zarf: Some Highlights of its History and its Implications}

Ibn Quzmān, the highly gifted and resourceful zajal composer in al-Andalus (d. 1160), tells us (zajal 35, str. 5) that the minute a man falls in love, he acquires zarf or, in the poet's own words, yirja 'zarif 'becomes refined and gentlemanly'. He then, the poet tells us, dons white shirts, clean shoes, keeps his hair washed, and develops a cheerful and witty demeanour.

In a gush of self-praise, bordering perhaps on narcissism, Ibn Quzmān also makes us understand that the zarf which was most highly prized in his own day, was that of the people of Iraq, just as the most genteel and high-class society of the day was that of the Iraqi capital, Baghdad:

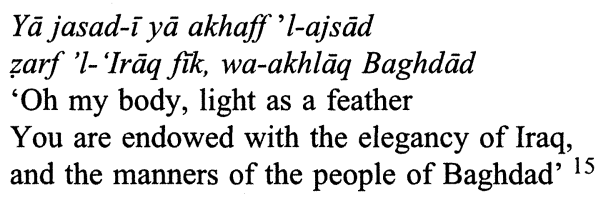

Long before Ibn Quzmān, Ibn Rashīq al-Qayrawānī (d. 1063 or 1070) ${ }^{16}$ in his work on the art of poetry, al- 'Umda (I: 257), states that

couplets of a muwashshah are known as mațla', a noun of place and of the form maf'al, then the end couplet or couplets should accordingly be termed makhraj. But it is to be presumed that the poets did not want to use a term which is reminiscent of anatomy and the lower end of the alimentary canal, and opted instead for kharja.

${ }^{15}$ Corriente's translation into Spanish (1996: 106) does more justice to the original Arabic:

"!Ay, mi cuerpo, de todos el más sutil!

La gracia de Iraq tiene, las maneras de Bagdad".

Gracia is perhaps one of the best renditions of zarf that we have in any language.

${ }_{16}$ In the recently published Encyclopedia of Arabic Literature, Ibn Rashiq appears under the entry «Ibn Rashiq al-Qayrawānī», but in another long entry, entitled "Maghrib», Ibn Rashīq's name is given, and consistently, as «Ibn al-Rashīq». In the entry on the author also the title of his well-known critical work al-'Umda is translated literally as 
poets have a well-known diction and metaphorical usage, alfäzun ma 'rüfa, wa-amthilatun ma'lüfa whose limits they should not overstep or infringe, unless, as he adds, «a poet should choose to introduce a comic effect (yatazarraf), by using non-Arabic terms»:

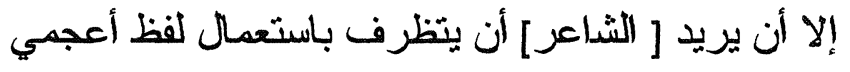

If, as pointed out above, the kharja is a sally of wit or wittiness, the use of foreign terms or expressions in it, according to Ibn Rashiq, is a constituent part of that wit, or of the comic effect that is intended.

When Ibn Rashiq refers to the use of foreign terms in poetry for macaronic purposes, tazarruf, he quite benignly allows for that if a poet, as he says, uses it sparingly, $f \imath^{\prime} ' l$-nudra, and he singles out for examples of such admissible moderate use of foreign words the poetry of al-A'shā in pre-Islamic times, and the poetry of Abū Nuwās nearer to his time:

Fa-yasta 'milu-hu fì 'l-nudra ... kamā fa 'ala 'l-A shä qadìman wa Abū Nuwās hadithan ... (I: 257).

But when Ibn Rashīq credits the early Abbasid poet Abū Nuwās with tazarruf for using lafz a 'jami or foreign terms and expressions in his poetry, and sparingly at that, he is simply touching the surface of the zarf for which Abū Nuwās was renowned, or he is like someone who describes the sea by describing a few goods cast up as waif by the sea. Nicholson (292) describes Abū Nuwās as «a great poet who ... takes rank above all his contemporaries and successors, including even Mutanabbī, and is not surpassed in poetical genius by any ancient bard.»

Few people anywhere have given us as fair and authoritative an assessment of classical Arabic literature as Nicholson has done. But Nicholson had no reason as we do to single out for comment the zarf for which Abū Nuwās was known, or to speak of his influence on the

'The Support', a translation which has no relevance whatsoever to the contents of the work. One wonders why modern scholars do not adopt the translation of an authority like Nicholson 'The Art of Poetry', which is what Ibn Rashīq's work is about. It should be pointed out also that the editors of the Encyclopedia do not seem to have noticed that they have given their readers two separate entries on an older contemporary and compatriot of Ibn Rashīq, and that is Ibn al-Raqīq al-Qayrawāni. The first is entered under the latter name, while the second appears under the heading «al-Raqiq al-Nadìm (also known as Ibn al-Raqī)». Under the entry «Maghrib», Ibn al-Raqiq is referred to as «Ibn Raqīq». 
poets of al-Andalus, and particularly on muwashshah and zajal composers. If Abū Nuwās was a colossus in his versatility and resourcefulness as a poet, he was equally a colossus in Arabic literary history for his zarf. He had that supremely saving humour which allowed him to speak of the most indelicate of subjects with a disarming charm and grace. When Ibn Quzmān, quoted above, speaks of zarf al-'Irāq as being proverbial, there is more than one indication in his zajals $(63,4$ and 123,3$)$ that Abū Nuwās was paramount in his mind. When al-A'mā al-Tuṭilì, likewise, speaks of knocking at the doors of a monastery at night with his pals in order to get some wine, wa-lamma taraqnā dayra khammāri (Ghazi, I: 303), he was no doubt trying, despite the distance in time and place, to «be a party to» the escapades of Abū Nuwās and his friends in the many monasteries which still dotted the area around Baghdad in the poet's day (Abū Nuwās: 153, $155,164,362$ etc.)

Yet, for all this, Abū Nuwās' influence on classical Arabic literature, as a whole, was paramount for other predominant and abiding considerations. We are often reminded that it is high society anywhere which usually sets the social trends, and gives glamour and currency to erstwhile taboos. Abū Nuwās was a much loved and prepossessing court poet at one of the most powerful and revered courts of his day, the Abbasid court in Baghdad. He was even a companion and confidant of one of the Caliphs of the day, the Caliph al-Amin. Abū Nuwās, the courtier, gave zarf in literature both vogue and repute. His wine songs, likewise, had a fascinating appeal which neutralized criticism, and set them as examples of excellence for other poets to emulate. When an early muwashshah composer like Ibn Rāfi“ Ra'sah as good as decrees (Ghazi, I: 19):

\author{
Al-rāhu wa-'l-ruḍābu mā fí-himā haraj \\ Illä li-kulli bid' $i \quad$ 'an dini-nä kharaj \\ 'Wine and the nectar of the beloved's mouth entail no sin or crime, \\ Except for heretics who have swerved from our (rightful) creed';
}

or when al-A'mā al-Tuṭilī (Ghazi, I: 285) uses hayya 'alā hānati khammāri as an analogue to hayya 'alā 'l-salät, both poets were clearly trying to emulate the illustrious courtier of Baghdad centuries before them. Abū Nuwās refers to zarf with a sense of panache on various occasions, and in varying contexts (Dīwän: 68, 187, 204, 424, 
$426,428)$, and he immortalizes the proverbial dictum tïhu mughannin, wa-zarfu zindiq 'the pride of a singer and the biting wit of a heretic', in one of his verses (Diwwän: 453). It is significant in the light of the discussions which follow, however, that the poet applies the dictum to a slave girl he admired and who seems to have been both a great wit and a charming singer.

It is safe to conclude from the preceding discussion that zarf goes back a long way in Arabic literary history. Ibn al-Qazzāz, as we have seen, speaks of sunnat al-zarf 'the law or traditional practice of zarf'. But talk of sunnat al-zarf was not something new in his time or his milieu. A good century before Ibn al-Qazzāz, Abū 'l-Ṭayyib al-Washshā' of Baghdad (d. 936) had written about sunan al-zarf «the laws or established practices of zarfin. Indeed, al- Washshä' entitles a long and pivotal chapter of his best known work Kitāb al-Muwashshā, ${ }^{17}$ Chapter XIV, «bäb sunan al-zarf» (1324 A.H.: 32-51 and Garulo, 1990: 68-101). Al-Washshā' may have wished to perpetuate his name by giving his work the title al-Muwashshä which reveals little about the contents of the book. But he tells his readers early on in the work that he is dedicating himself in it to a description of zarf, and what it behoves the zarif, the man endowed with zarf, to adopt and to relinquish of manners (1324 A.H.: 32, Garulo, 1990: 66). But more than that, when the book was published in modern times in the Arab world, it invariably appeared, as Garulo points out (1990: xxxi), with the subtitle al-zarf wa-' $l$-zurafa $\bar{a}$ ', indicating that its readers looked at it as a treatise on zarf, and the deportment and refinement of those endowed with it, the zuraf $\vec{a}$.

Al-Washshā', however, clearly seems to espouse zarf as an ethical ideal which he defines by association with two other ideals, murü'a 'virtue' and $a d a b$ 'good-breeding, courtesy'. This trinity of virtues, he insists, do not only compliment each other, but do not subsist, any one of them, without the others: lä adaba li-man lä murü'ata la-hu, wa lä murü'ata li-man lä zarfa la-hu, wa-lā zarfa li-man lä adaba la-hu (1324 A.H.: 1 and 2, and Garulo 1990: 5 and 7). Other important attributes of the zarîf are variously enumerated by al-Washshä' as fașăha 'eloquence', and a close synonym balägha 'sharp, effective

\footnotetext{
17 My references to al-Muwashshā are to an early edition by M.A. al-Khānjī, Cairo, 1324 A.H., and to the excellent study and translation into Spanish by Teresa Garulo, entitled El Libro del Brocado, Madrid, 1990.
} 
speech', nazäha 'honesty', hayā' 'propriety', karam 'liberality', and wara' 'piety'. But the attribute, which recurs most often is 'iffa 'chastity'. All this makes it clear that al-Washshā' treats zarf as a meritorious ethical ideal, or, as Garulo so aptly points out about al-Washshā"'s work (1990: xxxi): «Es una obra de adab y, como tal, tiene una finalidad claramente didáctica». A contemporary of al-Washshā', Ibn Dāwūd al-Isbahānī (868-910), likewise stresses 'iffa 'chastity' as a basic attribute of zarf in two early chapters of his well-known anthology of poetry entitled al-Zahra (117 and 126). He entitles Chapter 8 of his work with the injunction «Whoever Wants to be (known as) a Zarif, Let Him be Chaste, 'afif ». The title of Chapter 9, likewise, stipulates that «It is a Travesty of Zarf to Describe the Beauty of the Beloved and Demeaning to Him/Her». ${ }^{18}$

One should not miss to note here, however, that Ibn al-Khatị (d. 1374), himself a muwashshah composer, and the compiler, besides, of the anthology Jaysh al-Tawshị, shares no common ground with either al-Washshā' or Ibn Dāwūd. His creed concerning zarf is clearly that of Abū Nuwās more than five centuries before him. In a muwashshah attributed to him ('Udda: no. 135), he speaks of sharī'at al-zarf, a creed, which, as he tells us, does not censure drinking and the fellowship of boon companions, nor reprove «the talk of the men of old about love and drinking.»

Lexical definitions of zarf of a later date, as in Lane (art. zarf), and hence, of course in Lisān al- 'Arab, do stress the ethical high ground patronized by Ibn Dāwūd and al-Washshā', and include 'good breeding', 'good manners', 'politeness', 'polite accomplishments' among the definitions of what is a highly polysemic term. They stress with al-Washshā' too the importance of 'beauty of expression and eloquence' and 'acuteness of intellect' as attributes of zarf (Lane and al-Fayrūzābādī: art. zarf). But the lexicons, like al-Washshā', fail to stress the literary function of zarf, the ability to excite mirth and admiration for which Abū Nuwās and other libertine poets of his contemporaries were preeminently known. ${ }^{19}$ Indeed Abū Nuwās came to be renowned in the Arabian Nights, although «-in a completely

18 The reason Ibn Dāwūd gives for this, is that the description of the charms of the beloved by the lover would simply arouse the passions of others for those same charms.

19 Among the poet's contemporaries, the equally light-hearted and profligate al-Ḥusayn ibn al-Ḍaḥhāk cannot be overlooked in this context. 
unhistoric manner-, as Hārūn al-Rashīd's court jester», ${ }^{20}$ on account of his sharp wit, and the mirth he aroused in his poetry. The muwashshah composers, emboldened by his example, as I have indicated earlier, tried to introduce hilarity or jesting and mirth into their kharjas. This is not to suggest, however, that Abū Nuwās' coincidental fame as a jester is to blame for any hapless kharjas in Arabic or Romance, or mixed Arabic and Romance in the muwashshahät. The kharja as zarf was meant to arouse admiration and to entertain with a combination of wittiness and pointed verbal effects. But, as is often the case, wittiness or humour in the hands of hapless poets or hapless comics quickly descend to the levels of the wanton and the obscene, or, as Maxim Gorky reminds us (130), they end up in «shameless and vicious talk about that great mystery» which is «the source from which spring all peoples and all tribes». In Gorky's memoirs, it is the washer-women who indulge in such talk when they are working together. In the next part we shall see why the muwashshah poets made women the protagonists of «shameless and vicious talk» in a wide range of their kharjas.

\section{Zarf and the Woman's-Voice Kharjas}

Has There Been a Missing Premise in the Study of the Woman's-Voice Kharjas?

As pointed out in the introduction to this article, whatever constitutes a puzzle or an enigma, stops to be enigmatic once its raison d'être is known. The muwashshahät, as we know, deal, practically invariably, with love and bacchic themes, which quite often overlap, and panegyrics. If it had been the purpose of the muwashshah composers to introduce love songs or cancioncillas de amigo at the end of their muwashshahs, the question should quite naturally have been raised as to why the love theme in the muwashshah should, so to speak, be segmented or divided with the principal part of it appearing in the main body of the composition and another part or snippet of it appear at the end as the kharja. Nor do the anomalies the kharja pres-

${ }^{20}$ See the short, but most informative article on the poet by G. Schoeler in the Encyclopedia of Arabic Literature. 
ents when viewed as a lovesong end here. Editors of the diw $\bar{a} n$ of the libertine poet Abū Nuwās, a major influence, as already indicated, on both muwashshah and zajal composers, divide his love poems «into those addressed to young men (mudhakkarät - about two-thirds) and those addressed to women (mu'annathät - about one-third)». ${ }^{21}$ In a good part of the muwashshahät, the love declaimed in the main body of the composition is explicitly addressed by the poets to men or young men. The kharja is then, all too frequently, declaimed by a young woman (a khawd, ghäda, 'adhrā', and a range of other terms referring to a maiden in Arabic) decrying the afflictions of her own love. What literary considerations, one asks, can explain or justify such a glaring dichotomy between the kharja and the rest of the muwashshah?

Yet another anomaly presented by the woman's-voice kharjas seems more perplexing than the rest. The woman's-voice kharjas amount to violence within the body of classical Arabic love poetry. And I do not say this because a good number among them are in Romance or mixed Arabic and Romance. The woman's-voice kharjas in Arabic do just as much blatant violence to the tradition of classical Arabic love poetry as the most erring or «unblushing» among their Romance or bilingual counterparts. Apart from that, the woman's-voice kharjas in Arabic or Romance, or mixed Arabic and Romance, and the final strophes in which they are introduced, have usually little or no intrinsic connection with the muwashshahs in which they appear. They are, more often than not, adjuncts or appendages which can well be studied separately, or apart from the muwashshahs to which they are appended.

These two aspects of the woman's-voice kharjas, the violence they do to the Arabic poetic tradition, and their seemingly disjointed or, perhaps, "afterthought» status in the muwashshah, will be discussed in two separate Sections, A and B, in what follows. In the course of this discussion, it will, I hope, become clear that whatever might have been the function of some of these couplets if they existed prior to the muwashshahät, the purpose they served in the muwashshahät, was to end the muwashshah with a flourish or sally of zarf. It might well be, and it often is zarf gone awry, but there is no

${ }^{21}$ See the article on the poet by G. Schoeler referred to in $n .20$ above. 
other convincing rationale or raison d'être for these often meretricious, but hardly meritorious kharjas.

As the emphasis at the outset in this study was on hearing things straight from the horse's mouth, and letting the poets and the texts speak for themselves, examples from the texts will be imperative in what follows, but they will be kept to a minimum. It cannot be overstressed, however, that any examples used in one of the two Sections which follow can equally serve as illustrations in the other.

A. The Woman's-Voice Kharjas Amount to Violence within the Tradition of Classical Arabic Love Poetry

The kharjas in a woman's voice whether in Arabic or in Romance constitute a volte-face not known in Arabic love poetry before or after them.

Arabic poetry at all stages in its development pictures the woman as an idealized and inaccessible inamorata. Based in a solid and continuing tradition in pre-Islamic times, it pictures the woman as the provider of every solace that the inclement desert could not provide. Her stature was compared to supple boughs with tender shoots, shamärikh, which made up for lack of shade. Her kisses were not only «like the best of wine», but more so, they provided the ruda $\bar{b} b$, the much needed pure and cold water. Her teeth too had a cool refreshing and ambrosial quality, shanab, and their delightful brightness and lustre was referred to as zalm, a term synonymous with 'snow'. Besides all this, Arab women were idealized in a manner that is unique and peculiar to the Arabian desert. The gazelle, it would readily be agreed, is one of the most graceful and elegant of all God's creations, and the pre-Islamic Arab poets compared the dark eyes of their women to its eyes, their necks to its neck, and their slender shapely waists to its waist. The reddish brown colour, huwwa, lama, la 'as on a gazelle's lips became an attribute too of the much desired dusky brown colour on the back of women's lips. It should not be forgotten also, apropos of all this, that Arab legend evolved to a large extent round the figures of self-immolating poet lovers who, for considerations of tribal pride or tribal custom were often deprived of marrying the idealized or idolized women of their desire. The woman, as with 
the Provençal troubadours, was very much on a pedestal, and the poet practically invariably her worshipper.

As Arabic poetry displayed a remarkable homogeneity under all its different climes (Cachia: 71), Hispano-Arabic or Andalusi poetry continued to place woman on a pedestal of reverent regard. The idealizing image patterns of pre-Islamic Arabic poetry mentioned above, and a wide range of others besides, remained its choice and prominent image patterns in the muwashshahät as in the traditional qasida form.

It was only in the kharjas, whether in Arabic or in Romance, that a sudden transformation seems to take place. With the appearance of the first muwashshahs, the women declaiming the kharjas have changed roles. They are now the supplicants, entreating earnestly for love. ${ }^{22}$ They no more represent or symbolize the solace the poets looked for. It is they, to all appearances, who are looking for solace. But more intriguing than all this, the poets still speak in the main body of the muwashshah of their love, or perhaps of their ilf or male companion with adulation and adoration, and then we hear a woman, out on a limb in the kharja, wondering how, where, or whether at all she could be able to meet her lover. The woman in the kharja is not any more the inaccessible inamorata, nor is she a «dream woman». Instead of her rid $\bar{a}$, her good will or approval being eagerly sought in the traditional gallant style, she can now, as we shall shortly see, be literally abused. In Section B below, we see her grovelling for favours or, in more familiar terms, selling herself for them. For those who still like to see an influence of contemporaneous Romance lyrics on the muwashshahät, such a meretricious transformation could not be the influence of lyrical Romance poetry in Spain or outside it at the time. And even if such an influence were to seem quite likely, the question would still arise as to why it affected only the kharjas while the idealized love in the main body of the muwashshah remained unaffected or untouched by it.

Two of the most poetic terms relating to women in classical Arabic poetry, and often paired together, are al-sadd wa-'l-tīh, unapproachability (lit. turning people away), and a stately pride. These prize terms, the prerogatives of the woman loved in Arabic po-

22 Abd al-Aziz al-Ahwani draws attention early on to this changed role of the women in the kharjas (1957: 18), but he does not go on to explain the phenomenon or to draw any conclusions from it. 
etry, catch us off our guard in the context of the kharjas by being turned into the prerogatives of men who play hard to get, and have an overweening pride with young women seemingly besotted by them. It is this startling development, it would seem, which made the Arabic verses introducing kharja $\mathrm{V}$ (V in García Gómez, 5 in Jones) occasion much confusion to readers both in the past and in our own day. I give below the strophe in which kharja $\mathrm{V}$ appears ('Udda: no. 102, Ghazi, I: 303-5) with the Romance text of the kharja as it has been transliterated and translated into Spanish by García Gómez (1975: 112): ${ }^{23}$

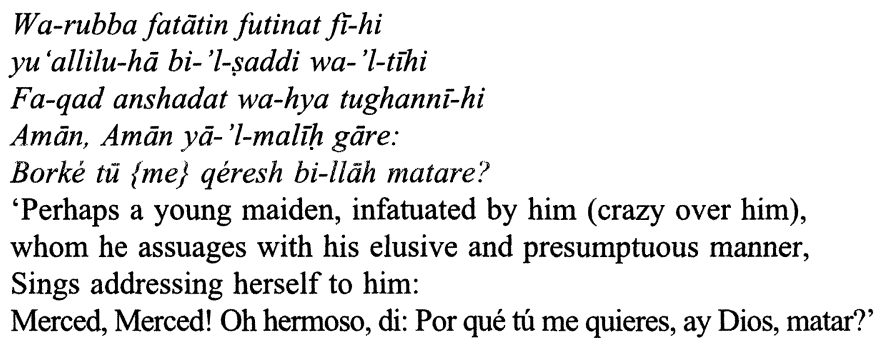

The copyists of the manuscrit Colin, who try the reader's patience at every turn, having some familiarity with the Arabic poetic tradition, must have readily «volunteered» to substitute the feminine $t u^{\prime}$ 'allilu-hu for $y u$ 'allilu-ha in the introductory lines, but without any awareness, it would seem, of the glaring contradiction which such a reading introduces into the text. With their «emendation» we would have to read:

'Perhaps a young maiden madly in love with him Lulls and assuages his passion with her disdain and pride'

Stern (1953: 24) reading, no doubt, $t u$ 'allilu-hu, translates with the obvious contradiction:

'Une jeune fille, fascinée par lui, le traite avec dédain'.

23 I have introduced minor amendments in the transliteration for the sake of conformity with the system used in this study, and I have read bi-lläh rather than $y \bar{a}-l l a \bar{h}$ of the manuscript, which neither classical Arabic, nor any Arabic dialects seem to confirm in such a context. 
More recently, Jones (1988: 56) has likewise retained the reading tu'allilu-hu. ${ }^{24}$ Jones, besides (57), gives the verb 'allala its literal denotation 'to attribute the cause of something to someone', as he puts it, instead of its conventional poetic implication 'to lull' or 'to assuage'. His translation (56) is quite far-fetched:

'There is many a maid who has become smitten by love of him, Attributing that to his refusal to meet her and his disdain, ... 25

One remark on kharja $\mathrm{V}$ should not be missed here, in anticipation of the following Section. In the opening two stanzas of the muwashshah in which kharja V appears ('Udda: no. 102; Ghazi, I: 303-305), the poet, al-Tutîlī, addresses with the respectful second person plural pronoun the lady (at a monastery) serving him and his companions the much desired wine. In the third and fourth stanzas, the poet speaks of his loved one, whom he explicitly and candidly refers to by his name Ahmad. In keeping with the common practice in woman's-voice kharjas, however, the young woman who declaims the kharja is referred to in the third person. She is not only introduced out of the blue, but at best, has the simple role of a «supporting actress» or, perhaps, an «extra». She remains unknown, and, what is more significant, has little or nothing to do with the main body of the poem.

And that most disreputable, and most readily remembered of all kharjas, no. IX in García Gómez (9 in Jones, 29 in Stern and Heger), tells us a lot about the function of the kharjas, and why so many of them are declaimed by women. It has, in my view, been best transliterated and translated by García Gómez, and I give below his transliteration and translation of it into Spanish. ${ }^{26} \mathrm{I}$ have

\footnotetext{
${ }^{24}$ In his edition of the manuscrit Colin ('Udda: 156), Jones retains the term in its feminine form, and without any comment on it in his footnotes.

25 Jones misses too the meaning of $t i h$ in the context of the present kharja and kharja 13 (107) where he translates the term as 'confusion'. It should be pointed out apropos of kharja V that García Gómez (1965: 80; 1975: 116), Sola-Solé (169) and Ghazi (I: 305), all emend the manuscript reading $t u$ 'allilu-hu and read yu'allilu-hā instead.

26 Stern's reading (1953: 26) clearly misses the logic of the Arabic exceptive particle $i l l \bar{a}$, and he reads and translates "Tan t'amaray ...» instead of the negative "Non t'amaray ...», Sola-Solé's reading (290) is unnecessarily involved, and he suggests the reading tar' $\bar{a}$, as an imperfect form of the verb ra' $\bar{a}$ which is hardly ever in use. Jones (1988: 88), although fully aware of the classical Arabic prototypes, so to speak, of this kharja, has emended the text of its second hemistich in many ways which both the fac-
} 
again standardized the transliteration in keeping with the system used in this study:

\author{
Non t'amarēy illā kon al-sharți \\ An tajma'a khalkhälī ma'a qurțī \\ 'No te amaré sino con la condición, \\ de que juntes mi ajorca del tobillo con mis pendientes'
}

It is this kharja, with a number of similar others, which prompt Margit Frenk Alatorre (115-116) to make the remark in her survey of the kharjas that «En muchas el amor no es virginal ni angustiado ... La mujer toma el papel activo; ... Es ella la que, en la no. 29 [in Stern and Heger], pone las condiciones para el acto amoroso».

One hopes that Frenk Alatorre did not mean to suggest by all this that women in al-Andalus led a free way of life, or were proactive to the extent of deciding in a brazen and unprintable way «las condiciones para el acto amoroso». The situation in reality was something other than that, and we badly need to look for an explanation as to why women were given roles in declaiming the kharjas, and why, in the process, they do not only seem to forget their manners, but quite often speak with impudent audacity.

The young woman who, as Frenk Alatorre says «pone las condiciones para el acto amoroso» is totally out of keeping with the tradition of classical Arabic love poetry, and, I dare say, out of keeping too with any lyrical Romance poetry which could have been known or current at the time in al-Andalus. It should also be pointed out, in anticipation of Section B below, that the kharja in question is out of keeping with the muwashshah in which it appears ('Udda: no. 140, Ghazi, II: 615-617). In the penultimate strophe the poet speaks

simile text he provides and Arabic usage do not support. His use of the intensive form tujammi instead of tajma', and the dropping of both long and short vowels, make it difficult to read his version either as classical or vernacular Arabic. Tujammi', apart from being incompatible with $m a$ ', implies 'to assemble' and not to 'bring together' (two parties or objects). Al-A'mā al-Tuțilī, who weaves this kharja into one of his classical Arabic verses, uses both jama ' $a$ and the infinitive noun deriving from it, jam ', for the purpose (Diwān: 119): Mã jama'a 'l-unsu li-ahli 'l-hawā Ka-'l-jam 'i bayna 'l-qurti wa-'l-hijli

Jones' reading of the second hemistich of the kharja is practically the same as Ghazi's (II: 617). 
very much in the classical style, of a love which holds no hope of reward or attainment:

Bī hawan mā fì nayli-hi amalu

Yet, in the last strophe, in the lines introducing the kharja, instead of the poet making a daring effort to visit a seemingly inaccessible inamorata, he invites her to visit him, pleading his dispiriting melancholy:

\section{Qultu zūrī afdī-ki mukta'ibā,}

and she readily accepts the invitation with a coquettish 'condition' or shart which promises to satisfy his anguished desire.

The disparity between the kharja and the tradition of Arabic love poetry, and the inconsistency that kharjas present with the rest of the muwashshah both need an explanation.

Deyermond (73) raises the question as to whether it is possible that the kharjas "are wholly mimetic, the artificial creation of male poets of the court?» This study does not for one moment claim that any society, Arab, Mozarab, Galician, Aquitaine, etc. lived without its songs and its primitive or developed love poetry. As the Arabic dictum puts it: kullun yughanni 'ala Laylā- $h$ 'Everyone strings a tune to his Leila'. As some of the Arabic kharjas are quite clearly verses from classical Arabic poetry, there is no denying likewise that some of the Romance kharjas existed prior to the muwashshahs in which they appear. What this study, however, based as it is on the texts, tries to establish, is the definitive purpose for which verses from classical Arabic poetry, couplets in vernacular Arabic or Romance, as well as «creation», to use Deyermond's term, and adaptation or manipulation of existing texts, were all mobilized for the provision of what was deemed to be brisk kharjas. If also, both the Arab and Hebrew poets were noble enough to allow women's voices a role in their muwashshah compositions, why, it should be asked, did they limit or confine that to the kharjas?

In the case of kharja IX, the fair-minded reader will readily perceive that the purpose of the exercise in the whole muwashshat ('Udda: no. 140; Ghazi, II: 615-617) seems to be to condense into a prize kharja a sensational «porn» scene which libertine Arabic poetry 
both in the Arab East and in al-Andalus had already popularized. It was García Gómez, one of the most competent scholars to deal with kharja studies, who first drew attention to the Arabic provenance or ancestry of kharja IX in various Arabic poetic texts in al-Andalus, including one Arabic kharja which has no admixture of Romance (1952: 92, notes 1 and 2, and 1965: 112-113). Jones (1988: 88, n. 9) points out the occurrence of a version of the same scene in the poetry of Abū Nuwās in the Arab East some three centuries before the muwashshahāt and their kharjas. It is only to be regretted, however, that García Gómez, after having identified the Arabic provenance and obvious Arabic prototypes of kharja IX, went on to classify it and study it as a Romance kharja, thus prompting other scholars after him to study it in the same light. ${ }^{27}$

If kharja IX should look like an extreme case in being sensational and pornographic, kharja $\mathrm{X}$ is not at all far behind. Kharja $\mathrm{X}(\mathrm{X}$ in García Gómez, 10 in Jones) literally, or perhaps I should say physically, represents violence within the tradition of Arabic love poetry because it depicts in the verses introducing the kharja a young woman being abused with wilful violence (Ghazi, II: 620; 'Udda: no. 149):

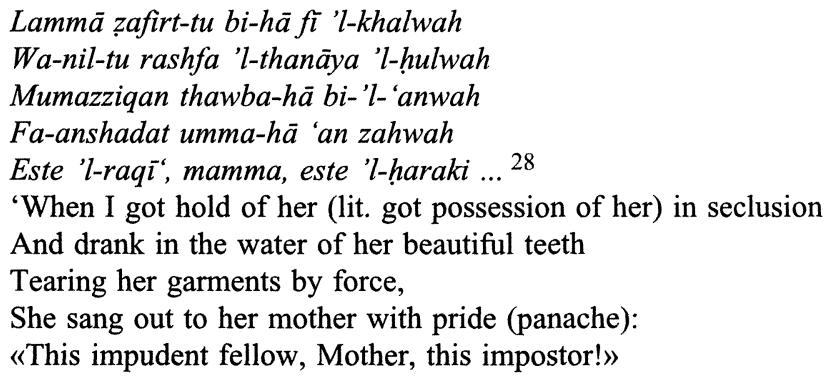

${ }^{27}$ Readers might like to consider the fact that any Arabic equivalents of non t'amaréy in the first hemistich of kharja IX, like lan ahwä-ka, la uhibbu-ka, etc. would not fit the metrical pattern. The use of the preposition con in the same hemistich might not have been altogether deliberate either. The poet might well have thought of using ma' $a$, only to discover that $m a$ ' $a$ appears in the second hemistich, and decided to opt for the Romance preposition to avoid repetition. There is no denying the macaronic effect of the Romance terms, but they could well have been used, as we shall shortly see, to convey the impression that the young woman declaiming the last two hemistichs is a Mozarab slave girl. I say «the last two hemistichs», because, strictly speaking, they do not qualify as a kharja. They make little sense if they are read independently, or apart from the muwashshah

${ }^{28}$ I have not given the rest of the kharja because it has not so far been satisfactorily read and interpreted. The transliteration is that of García Gómez (1952: 93) with vowel $i$ added to the last term. 
If we are to believe what the last introductory verse says, then the poet is telling us that the young woman concerned did not view what had happened to her as the grievous affront that it is, and we would have to accept the terms 'impudent' and 'impostor' as being used with playful or even affectionate undertones.

Yet this is the same poet who, in the main body of the muwashshah ('Udda: no. 149; Ghazi, II: 618-620) has given us one of the most gripping poems in the whole corpus of the muwashshahät that is nobly dedicated to the idealization and adoration of women. That the purity of the poem is not free from conventional usage, or the ever-present trappings of badī' (discussed in Part I) does not mar, or detract from the idealization of the poet's beloved in each one of its stanzas. At the end of the first stanza he says to his beloved:

\footnotetext{
'You are the $K a$ ' $b a$ of all beauty; it is to you that my soul longs to make every pilgrimage, its hajj and its 'umra, ${ }^{29}$ and the offerings I bring are the very organs of my body'.
}

At the end of the second stanza, he says to her with equal fervour, though not resisting a minor tribute to $b a d \bar{l}$ :

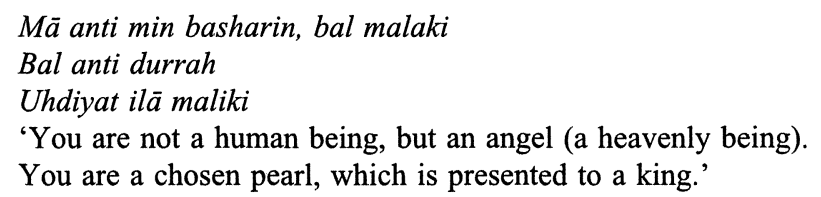

Readers will note the near-total paronomasia between malak and malik.

One footnote to the muwashshah discussed here should not be missed out. In the course of his adulation of the woman he loves, the poet supplies the most apt Arabic equivalent for the Provençal terms obedienz or obediensa, and that is al-khudiu' 'obeisance' (stanza 4) as an act of reverence on the part of the poet towards the woman he loves. The term constitutes a part of the psalmodic adoration and uplift in the rest of the muwashshah. But as I have said at the outset in this Section that the woman's-voice kharjas constitute a volte-face in

29 This is the minor hajj which entails fewer ceremonies, and need not be performed at a specific time of the year. 
the tradition of Arabic love poetry, it is quite revealing to note here

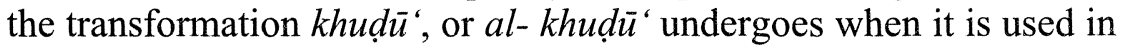
a woman's-voice kharja by the poet al-Abyad, in his best-known muwashshạ, Mã ladhdha lī shurbu rāḥi ('Udda, no. 71, Ghazi, I: 400-402).

In the main body of al-Abyad's poem, it should be stressed, the poet's love treats him (stanza 2) with the traditional sadd, avoiding him, or even being averse to his advances. The kharja is in Arabic, and the young woman declaiming it addresses herself to her lover, al-khalīl, with khudu' ', which clearly refers in the context of the kharja to the abject submissiveness of the young woman to her lover. The three protagonists in the kharja (reproduced below), the young woman, her lover, and her messenger to the lover, have no connection whatsoever with the poet and his tirade on his own love in the main body of the muwashshah:

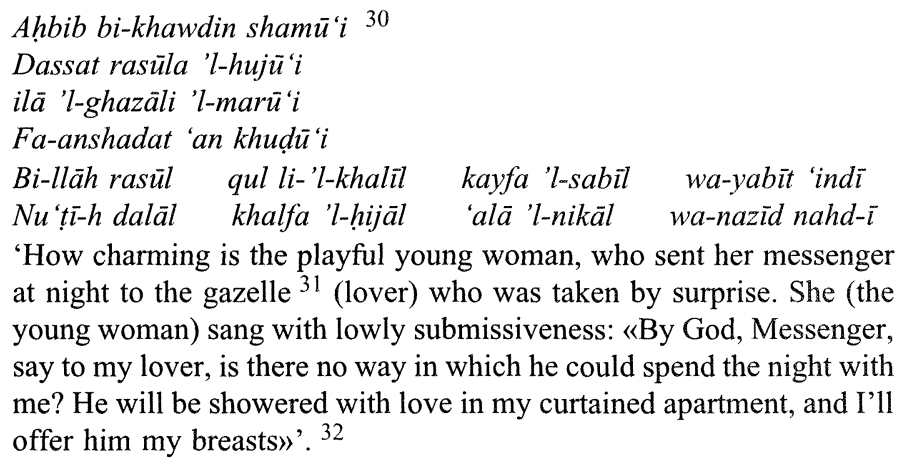
at night to the gazelle ${ }^{31}$ (lover) who was taken by surprise. She (the young woman) sang with lowly submissiveness: «By God, Messenger, say to my lover, is there no way in which he could spend the night with me? He will be showered with love in my curtained apartment, and I'll offer him my breastsı'. 32

Kharjas, like nos. IX and X, the Arabic kharja just surveyed, and many others besides, in Arabic and Romance, were perhaps libertine poetry at its most blatant. But Arabic libertine poetry had preceded

${ }^{30}$ The lexical definitions of the epithet sham $\bar{u}$ ' are highly indicative as to how the women declaiming the kharjas were viewed by the poets and indeed by the society of the day. The epithet, practically invariably applied to women, implies, among other things, a woman «That jests, or jokes much»; or that is «playful, sportful, or gamesome, and wont to laugh»; or a woman «that kisses one, and will not comply with one's desire otherwise than by doing thus» (Lane, art. Shama' $a$ ).

31 From the earliest of times in pre-Islamic Arabic verse, 'gazelle', in the masculine gender, referred to the beloved young woman.

32 It would have been noticed that for exigencies of rhyme and metre the poet uses the singular form, nahd-i, in Arabic. 
the kharjas both in the Arab East, ${ }^{33}$ and in al-Andalus. It was not something novel in the Andalusi literary scene when the muwashshahāt were being written. What was novel in the libertine kharjas in al-Andalus was to make the libertinism every so often more notorious, or more sated by making women declaim the kharjas. While libertine kharjas would no doubt be diverting and titillating when declaimed by the poets themselves, when declaimed by women they start to offer, so to speak, the promise and sensations of $\mathrm{x}$-rated films, or, in plain terms, an element of pornography.

While the poets could not have, or could not even picture free women declaiming their devil-may-care kharjas, they could readily find in the taverns of the day, or in everyday Andalusi life around them, the slave girls who would be pictured as declaiming provocative kharjas, as we have seen, or who would be «groomed» for any role which would add «spice» and «savour» to the muwashshah. Slave girls, as I point out further on, are the quantity which has so far been missing in trying to solve the equation of woman's-voice kharjas. Just as these second-class citizens were «used and abused at will» ${ }^{34}$ in everyday life, they were also «used and abused at will» for literary purposes by the poets to provide solace for those who read, or heard their muwashshahs declaimed, and who came to await and to expect that solace from the kharjas. Nor should it be forgotten in all this, of course, that the kharjas provided a chance for the poets themselves for psychological release and liberation - quite often a double release and liberation, both from social taboos, and from the strict demands of classical Arabic, be they demands of usage and grammar or of prosody.

33 The doyen of the Arab libertine poets Abū Nuwās, who is acknowledged as a major influence on the Andalusi poets, lived in the latter half of the $8^{\text {th }}$ century and beginning of the $9^{\text {th }}$ (755-813). If one goes further back, however, one can find explicit libertine poetry in the very first of the pre-Islamic mu 'allaqa $\bar{a}$, that of Umru' al-Qays. It is to be regretted, however, that two modern Arab scholars, 'Umar Farrūkh and A. Abū Shaqrā, have found it fit to expurgate the «offending» lines in their study of the poet. See their work Khamsat Shu 'arā' Jähiliyyinn, Beirut, 1363 A.H/1944 A.D., 21, where three verses are omitted from the poet's mu'allaqa without any reference to that in the footnotes.

${ }^{34}$ I am using the words here of the novelist Arundhati Roy who lists the present-day «Philippino cleaning lady, the Indian jamadarni, the postal bride from Thailand, the Mexican household help, the Jamaican au pair» as being among the second-class citizens of our day who «are used and abused at will». See her article "A strange kind of freedom", The Guardian, 02.04.03, 2-5. 
It should be repeated here that love themes, or any lyrical verses in the muwashshahāt, appear usually, like bacchic verses, either at the beginning as overtures or in the main body of the muwashshah. Kharjas in their multiple diversity, might no doubt in some cases introduce love themes, or as we have seen, downright sexual scenes (or what I have referred to as zarf gone awry). Verses from Arabic poetry also, as well as couplets in Romance, were either adopted as kharjas or incorporated with little change into other kharjas. These too might not lack some authentic lyrical strain or content. But whatever purpose or purport these might have had before they were «enlisted» as kharjas or parts of kharjas, their purpose or raison d'être in the context of the kharjas was to end the muwashshah on a vivacious or «hyped-up» note. ${ }^{35}$

\section{The Kharja which Best Tells the Story of All Woman's-Voice Kharjas}

A kharja which does manifest violence to the tradition of Arabic love poetry, and which better and clearer, perhaps, than any other tells the story of all woman's-voice kharjas in Arabic or Romance is the very first kharja - first at least in the editions of García Gómez (1975: 79-89) and Jones (25-34). It is also a kharja which provides with clarity and without ambiguity what I have already referred to above as the missing quantity in the equation of the woman's-voice kharjas. This missing quantity is the fact that these kharjas are declaimed by slave women, or are presumed to be the preserve roles of slave women. What has helped to disguise this missing quantity, and make scholars seemingly unaware of it and of its significance, is the reference to slave girls who declaim the kharjas by such poetic and ennobling Arabic terms like ghäda, hasnā', 'adhrā' (this is the Arabic term for The Virgin when it is defined), khawd, fatät, zabya, etc. Such terms, and others besides, help to disguise the insensitive debasement of these women and help to raise the woman's-voice kharjas a grade or two at times above the level of sheer carnality and turpitude. The kharja I am referring to is that of the muwashshah Min mawridi

\footnotetext{
${ }^{35}$ One could use a term popularized by British politics in recent times, and say that
} the role of the kharja in such cases was to "sex up» the muwashshah. 
'l-tasnīm by Muhammad b. 'Ubāda al-Mālaqīi 36 ('Udda: no. 22; Ghazi, I: 184-186). As I have already indicated, this is a kharja which in a highly prosaic and matter-of-fact way gives away the identity of the young woman declaiming it. I reproduce it here as it has been transliterated and translated by Garía Gómez (1975: 86-97), but I give my own reading and translation of its introductory lines:

$\begin{array}{ll}\text { Wa-ghädatin lam tazal } & \text { tashku liman lā yunșifu } \\ \text { Yã wayha man yattașil } & \text { bi-habli man lā yus 'ifu } \\ \text { Lammà ra'at-hu batal }{ }^{37} & \text { wa-hya gharäman taklafu } \\ \text { Ghannat wa-mā li-'l-amal } & \text { illä ilay-hi 'l-mașrifu }\end{array}$

36 Jones (1988: 25), in his study of the present kharja, omits the nisba of the poet «al-Mālaqī» which appears in his edition of 'Uddat al-Jaliss (33), without pointing that out to his readers or giving any explanation for the omission. Having thus called the present poet «Muhammad ibn 'Ubāda», he does students of the muwashshahät a disservice when he goes on to say that «Stern argued cogently that references to Muhammad ibn 'Ubāda and to 'Ubāda were not references to two different poets but to the same one.» $\mathrm{He}$ goes on to affirm that «The manuscript of 'Uddat al-Jalis offers conclusive proof for this proposition». What Stern in fact did in the article Jones refers his readers to $(33, \mathrm{n} .1)$, "Muhammad ibn 'Ubāda, al-Qazzāz, un andaluz autor de muwashshahas" (Al-Andalus $\mathrm{XV}, 1950,79-109$ ), was to try to settle the problem of the name of the panegyrist and court poet of al-Mu'tașim b. Șumādih of Almería whose name appears in various sources as Muhammad Ibn 'Ubāda al-Qazzāz, "while two other sources mention a certain 'Ubāda al-Qazzāz, also an author of muwashshahsı» (79-80). Stern poses the question as to whether there were in the court of al-Mu'tasim in Almería «two authors of muwashshaḥs, one called 'Ubāda al-Qazzāz and another Muhammad ibn 'Ubāda al-Qazzāz, or only one poet called Muhammad ibn 'Ubāda al-Qazzằz, and the name 'Ubāda al-Qazzāz is a mistake or deformation of the true name.» Stern concludes, quite cautiously, that in general «the second hypothesis appears to be the more plausible one» (90-91). Taking all this, it would seem, as a reference to «Muhammad ibn 'Ubāda / 'Ubāda», Jones presents his readers (25) with a mix-up of muwashshah composers and titles. The muwashshah Kam fì qudüdi 'l-bān which Jones (25) attributes to «Muhammad ibn 'Ubāda / 'Ubāda», is without doubt by Muhammad ibn 'Ubāda al-Qazzāz, the court poet of al-Mu'tașim b. Sumādih and his sons. It does not only have the name of the poet's patron, Muhammad, in the lines introducing the kharja, but it has the title which his patron assumed, al-Mu'tasim, mentioned in the kharja (The full name of the poet's patron, including the kunya, was Abū Yahyyā Muḥammad ibn Șumādiḥ al-Mu'taṣim bi-'llāh.) Apart from that, the last three stanzas in the muwashshah and part of the stanza preceding them are dedicated to the description and celebration of the fleet that Almería could still muster under al-Mu'tasim's rule, having been, under the Umayyads, the principal base for the Andalusi fleet (Äl-Qaisi: 12-19). It was García Gómez who first drew attention to Stern's article in 1952 (Al-Andalus XVII, 72, n. 1). But he too missed the issue in Stern's article, and went on to identify the author of Min mawridi 'l-tasnim with Muhammad ibn 'Ubāda al-Qazzāz, and to attribute Kam fi qudüdi 'l-bān to him (1965: 43 and 1975: 79 and 437).

37 I should make the remark again here (see Abu-Haidar, 2001: 165-166, n. 4) that Jones (26-27), without any credible justification, emends the manuscript reading batal and reads instead matal which he translates as 'delay fulfilment of his promise'. This, of 


Meu sìdi Ibrähim yā nuemne dolze fen-te mīb de nojte
In non, si non kerish yire-me tīb gar-me 'a 'ob a fer-te
'And a young woman of a «soft and tender» body,
has not ceased to complain to one who has no sense of justice
Woe to the one who seeks bonds (of love and friendship) with someo-
ne who offers no help
When she saw that he was untrue, and talking in jest, while she was
madly in love
She sang, and hope is always bound to be the only refuge to turn to': ${ }^{38}$
Señor mio Ibrahim, oh nombre dulce, vente a mí de noche
Si no -si no quieres-, ireme a tí: dime en dónde encontrate

For anyone giving a careful reading to the muwashshah Min mawridi 'l-tasnim and its kharja, closely examined here, two conclusions would be simply unquestionable:

The young maiden, the «inamorata» in the kharja is not inaccessible, nor, of course, is she a «dream woman». Instead of her favours being earnestly sought, she is seeking favours. More than that, she seems to beg for favours, or is ready to humiliate herself for them. This no doubt goes counter to the tradition of classical Arabic love poetry, or amounts to violence within that tradition.

But, to anticipate what is dealt with in the next Section, such woman's-voice kharjas in the large majority of the muwashshahāt have little or nothing to do with the main body of the muwashshah and its protagonists, whether these be the poets themselves, or their female or male companions.

course, dismantles the striking case of antithesis the poet sets up between the false and guileful attitude of a lover who talks in jest, and the earnestness of a young slave girl who is madly in love with him.

${ }^{38}$ In the fourth of the introductory verses, as can be seen, the poet sums up in a simple, but effectual way the universal truth that hope is always apt to be the last refuge for a care-worn or sorrowing humanity - wa-mā li-'l-amal illā ilay-hi 'l-mașifu. But it is rather indicative of the perfunctory state of kharja studies so far that practically all scholars who have closely examined the present kharja, as far as I know, have read the fourth introductory verse as a reference to the girl's master (Ibrāhim) and her persisting hope to be able to go and see him. Thus Stern (1964: 21) translates: «elle chanta et n'avait d'espoir que de se tourner vers lui», and more recently Jones (1988: 27), likewise renders the verse: «She has sung, when the only hope has been to go out to him».

One can find an equivalent to the poet's verse in John Dryden's verses (In Aureng-Zebe, Act IV, Scene I):

When I consider life 'tis all a cheat

Yet fooled with hope men favour the deceit. 
In the present case the ghäda who keeps complaining to one who feels no sympathy for her - lam tazal tashkü li-man lä yunsifu - has nothing to do with the poet, or his male companion who is referred to in stanza 2, as Abū 'Amr. The kharja and the verses introducing it are an entity apart from the muwashshah. And it is an indication of the speculative nature of both muwashshah and kharja studies that such tenuous links between woman's-voice kharjas in particular and muwashshahs in which they appear have not been seen in the proper light, so that sound conclusions could be drawn from them. The young maiden, the ghâda, declaiming the kharja in this case, is a slave girl addressing herself to her master, her dueño, Ibrāhīm. Neither she, nor her master appear in the main body of the muwashshah. They are not part of the dramatis personae of the muwashshah. They are, so to speak, the independent comedy actress and actor of an independent sketch which is the kharja and the last stanza introducing it.

Stern (1953: 21) makes no comment on the puzzling aspect of the young woman in the kharja and the «lover» she is addressing herself to. But Stern must have read ya rịha instead of $y \bar{a}$ wayha in the second verse introducing the kharja, and hence he translates, rather puzzlingly:

'Oh vent! Qui peut s'attacher à quelqu'un qui ne veut pas aider?'

Commenting on the two puzzling «supernumeraries», the slave girl and her master, one of whom has a speaking part, García Gómez, both in 1965 (43) and in 1975 (79), used a question mark:

«la [estrofa] 5 introduce la jarcha, como dedicada a ese mismo amado (?) por una mozuela enamorada (luego quizás el Abū 'Amr se llama Ibrähïm)». (The italic is mine).

Sola-Solé (115) omits the question mark, but makes no effort to clear the same obvious puzzle:

«La jarcha, al final de la quinta estrofa, está puesta en labios de una doncella que, enamorada del mismo mancebo, canta sus ansias por ver a Ibrähïm, acaso el primer nombre de Abū 'Amr». (The italic is again mine).

More recently Jones (1988: 26) comes to the same puzzling conclusion as García Gómez and Sola-Solé:

"It would seem that we should conclude from the use of the name Abu 'Amr in stanza 2, line 1, and of the name Ibrāhīm in the kharja that the 
person to whom the poem was originally dedicated was someone named Abū 'Amr Ibrāhīm».

\section{More on the Trivialization of Women in the Kharjas}

The trivialization of women in the kharjas of the muwashshahät and particularly in the woman's-voice kharjas can be explained by two closely related facts. The first is that zarf or wittiness in past and modern times alike, whenever it starts to feel wanting and shallow, falls back, as Maxim Gorky tells us, on «flogging to death» that great mystery through which all people are born in order to elicit entertainment value from it. The other fact is that Andalusi society had very much fostered that class of women, the jawäri who could be «used and abused at will» even for literary purposes.

This study, of course, is not primarily concerned with the social structure of Andalusi society at the time when the muwashshahāt were being written. But a few guidelines from three prominent students in the field should suffice to illuminate the scene for us, inasmuch as it bears on this study.

The contemporary historian of Hispano-Arabic or Andalusi literature, Ihsan Abbas, tells us repeatedly (1987: 66-68) that "slavewomen predominated in Andalusi society», inna 'l-mujtama'a 'l-andalusī kānat taghlubu 'alay-hi 'l-jawārì. Long before Ihsan Abbas, and much more competently and comprehensively, Julián Ribera (1928, I: 17-26) had told us as much when he produced from the medieval sources whole series or chains of actual contracts of sales and exchanges or emancipation of slaves, and particularly slave-women, in the markets of Toledo, Cordova, and what Ribera refers to as «las regiones marítimas de Andalucía». Readers might no doubt want to consult, too, in this connection, Teresa Garulo's work Diwān de las poetisas de al-Andalus (1986), where among the thirty-three women poets the author introduces in this work, with translations into Spanish of their surviving verse, she mentions no less than six poetesses to whom she refers as 'esclavas' or 'esclavas cantoras' (qiyān). Readers might want to note too that in her study of the most notable poetesses she refers to one (111) who is described in the Arabic sources as a mäjina 'poetisa desvergonzada'. Garulo characterizes her language as «popular y descarado» (110-111). Garulo 
refers to another poetess "who won the admiration of the following generations by her sharp tongue for which she was compared to the great poet Ibn al-Rūmī in the Arab East, well known for his satires»» (105). The significance of all this, and much besides, ${ }^{39}$ cannot be lost upon students of kharja studies.

B. The Woman's-Voice Kharjas Are Entities Apart from the Poems in Which They Appear

The interdependence between the last and the present Sections of this study cannot be overemphasized. I have already indicated that any examples given as illustrations in one of the two Sections, can just as well serve as illustrations in the other.

Three aspects of the last kharja to be examined in the previous Section stand out prominent and clear:

a. As has already been pointed out, the young slave girl who is entreating her master and lover to come to her, or to be kind enough to let her know how she could go and meet him, is a phenomenon which runs counter to the tradition of classical Arabic love poetry, in which the beloved woman is the inaccessible party.

b. The kharja and the verses introducing it, and the two protagonists who appear in it, the slave girl and her master, have nothing to do with the poet and his love for his ilf ${ }^{40}$ or companion. The latter is referred to by his kunya, Abū 'Amr, in the second stanza of the muwashshah, and he is the focus of the poet's affections. The self-contained fifth stanza (examined in the last Section), neither in its grammatical structure, nor by its content suggests any links with the other four stanzas of the muwashshah. Except in rare cases like kharja IX discussed above, where the sensational kharja is the focus of the whole muwashshah, the brief sideshow, so to speak, introduced in the last stanza is not a part of the dramatic scene in the rest of the muwashshah.

\footnotetext{
39 When she studies the life and verses of the renowned poetess Wallāda bint al-Mustakfi, Garulo refers to her «desprecio por las conveniencias» (142).

40 It is significant indeed for our purpose here and in a good part of the discussion which follows, that Ibn Hazm gives his well-known treatise on love, Tawq al-Hamāma, the subtitle, fi'l-ulfa wa-' l-ulläf, 'on companionship and companions' rather than 'on love and lovers' which might suggest exclusively heterosexual love.
} 
c. Attention has not been drawn in the last Section to the Sisyphean struggle the poet goes through in the matla ' of the muwashshah, and in each subsequent qufl before he gets to the kharja in order to reproduce in each case the eightfold-rhyme scheme of the kharja. ${ }^{41}$ This was a time in the development of Arabic literature, as I stress again further on, when difficulty of execution in writing passed for merit (Abu-Haidar, 2001: 121 and 133). The muwashshahät appeared at the same time when the highly formalized maqämät in rhymed prose were acquiring their vogue. The maqāmät of al-Hamadhāni (968-1007) antedate the appearance of any muwashshahs that we know of, or whose dates we can safely ascertain.

The last kharja to be discussed above, however, with its highly artificial multiple rhymes (and, of course, the equally factitious rhymes in the matla' and the rest of the aqfäl) should not give the impression that the muwashshah, as a new literary form, was totally «usurped» and turned into a literary exercise, to which, by all appearances, it readily and enticingly lent itself. While the poet of Min mawridi 'l-tasnim seems to have been carried away by the literary exercise, there were poets, few in number perhaps, who used the form in order to express through it harrowing love experiences, and a nagging and painful poetic intensity. But, for our immediate purpose here, even the best and «purest» among these poets had to pander to the custom of introducing a hyped-up kharja at the end. We have already seen the anonymous poet of muwashshah no. 149 in 'Uddat al-Jalis giving one of the most idealizing poems addressed to a woman in the corpus, and ending with a scene of blatant violation in the stanza introducing the kharja. The muwashshah and the kharja (no. X), as we have seen, have not the slightest kinship binding them together.

One of the simplest in form of all muwashshahs dedicated to love, but one of the most intense in the whole corpus is again an anony-

${ }^{41}$ For readers who do not know Arabic we should be careful not to shower with praise any such feats of prolific rhyme in the muwashshahät, as Jones does (1988:25) where he speaks of «the remarkable wa-haqqi sürati qäf ('Uddat al-Jalis, poem 309...), with its brilliantly successful tenfold-rhyming simts in the difficult rhyme of - $\bar{a} f$ »). The simplest test for the «brilliance» of any such verses of a tenfold-rhyming scheme is to try and render their content and "formal beauty» in another language. Such poetry, as Gibb (22) aptly puts it, «can never be satisfactorily translated into any other language, just because the thing said varies so little and the whole art lies in the untranslatable manner of saying it». And the truth is that such muwashshahs are the least read, and, quite naturally, the least known among readers. 
mous muwashshah ('Udda: no. 157). It is addressed to the beloved throughout, this time, in the masculine gender. García Gómez (1975: 157) sums up well the contents of the muwashshah and its relationship with its kharja. My difference with him in what he says is, as will be seen, one of emphasis:

\footnotetext{
«Es un poema amoroso, de ausencia, con los tópicos habituales: a la amada se la han llevado, [we have to read «al amado» throughout] pero ha quedado en las entrañas y en la retina del enamorado, quien sufre insomnio y extenuación, pero que se honra con ello, etc. La jarcha (invitación de una muchacha a su amigo para que le bese, aprovechando un descuido del espía) no guarda relación con el resto del poema». (The italics are mine).
}

García Gómez is perhaps right to say that the topics and language used in muwashshah 157 ('Udda: 238-239) seem habituales or conventional. But a special dignity is imparted to them throughout this time by their humbling sincerity. The arranque, the very first words of this simple or inelaborate muwashshah announce a powerful and defiant truthfulness:

$$
\begin{aligned}
& \text { Bi-za 'mihim ghayyabūk wa-bayna 'l-hashā khallafük } \\
& \text { 'They think they have taken you away (from me) when deep } \\
& \text { within me (en mis entrañas) they have left you' }
\end{aligned}
$$

Where García Gómez is absolutely right, is in saying that kharja XI (11 in Jones) «has no relation with the rest of the poem». The whole muwashshah, as already stated, addresses the beloved consistently in the masculine gender, while the kharja is declaimed by a young woman who, taking advantage of the inadvertence of the eternal espia, draws the attention of her lover to her «cherry-red mouth», and asks him to give her a kiss.

One can perhaps say in this case, however, that the only affinity between the kharja and the rest of the muwashshah is that the anonymous poet, impassioned and principled as he is, refuses to give in completely to tradition and sully his muwashshah with a salacious kharja. In fact, there is every likelihood that he chose a kharja that would impart dignity to his poem. Andalusi Arabic referred to cherries as $h a b b$ al-mulük 42 'the fruit of kings' (lit. grains), and the young woman in the kharja refers to her mouth as bokella de habb al-mulük. The zarf, the hyped-up kharja, is thus guaranteed an element of the grace and the dignity usually associated with kings.

42 See Corriente (1997) art. ḥbb. 
Sola-Solé (299) in his comments on this same kharja, points out, like García Gómez, that it has little connection with the rest of the poem. He goes on to point out, as his final remark on it, the active part that the young girl plays in it, and that «es ella la que desea y se ofrece al beso amoroso del amigo».

The last two witnesses I have produced that woman's-voice kharjas have little connection with the poems in which they appear are anonymous muwashshahs. And it might well be said that anyone making a good case does not produce "witnesses of no fixed abode». But Ibn Baqī and al-A'mā al-Tuṭilī are both «heavyweights» as muwashshah composers, and, together with Ibn Zuhr and Ibn Sahl, constitute the Big Four who get away with the best part of the laurels for the art.

Ibn Baqī, indeed, gives us Romance kharjas declaimed by women which give little heed to the tradition of Arabic love poetry, and which show little affinity or connection with the compositions in which they appear. The women declaiming the kharjas in his compositions appear unexpectedly in the last strophe. A good case in point is his muwashshah yā khalīlayya sa-alqā 'l-llāha min alami 'l- 'ishqi 'I will soon meet my maker, friends, because of the pains of love' (Ghazi, I: 480-482, and 'Udda: no. 344). In this muwashshah the poet complains of the anguish of his passion for a young man he loves, but ends with a final strophe in which he is dallying with a woman «whose delicate body can be scratched» even by his eyesight falling on it. She suggests as much when she warns him in the kharja she declaims that her undergarment is too delicate to be mishandled (kharja XXIIa in García Gómez; 23a in Jones).

Ibn Baqi uses the masculine form of address throughout in the main body of the muwashshah. But if any doubts at all were to be raised that he might be using the masculine form of address as a disguise, the poet dispels all such doubts in strophe 3 of his muwashshah where he describes his beloved as having all the charms of Rachel's son (Rạhill in Arabic), immortalized both in the Bible and the Qur'ān:

Sāḥiri 'l-țarfi rakhīmin, fì șifāti 'bni Rāḥili ${ }^{43}$

'With enchanting eyes, and gentle voice, and all the charm of the son of Rachel'

${ }^{43} \mathrm{Ibn}$ Zuhr (Ghazi, II: 66), probably for exigencies of rhyme and metre, calls Joseph Ibn Rähil. He too, like Ibn Baqī, describes his loved one in one of his muwashshahs as yüsufiyyu 'l-husni (Ghazi, II: 119). 
Ibn Baqi refers to the beauty of Joseph on more than one occasion in his muwashshahs, and in each case they are poems addressed explicitly to a male friend. In muwashshah 7 (Ghazi, I: 429-431) he says in a cheerful, buoyant mood (stanza 4), Li habibun yüsufiyyun 'I have a beloved who is very much the picture of Joseph'. ${ }^{44}$

But more than that. Should statistics be summoned as a witness, not one of the muwashshahs attributed to Ibn Baqi is addressed to a woman as his love. But no less than seven of these, like the present muwashshah, are explicitly addressed to men. There is, no doubt, an exception to every rule. But woman's-voice kharjas in muwashshahs addressed to men as the object of love have, without exception, little connection with the poems in which they appear. They are simply meant in such cases to supply the required bowing out element of zarf. ${ }^{45}$

Before leaving Ibn Baqī and his use of kharja XXIIa in García Gómez (23a in Jones), I should not fail to point out that the competent poet Ibn Ruhaym uses the same woman's-voice Romance kharja (XXIIb in García Gómez, 23b in Jones) in what is arguably perhaps his most notable muwashshah, yā nasima 'l-rīhi in 'ujta 'alā rabbati 'l-qurți (Ghazi, I: 349-351, 'Udda: no. 345, and Jaysh, Section 13, no. 2).

While Ibn Baqi violates the tradition of classical Arabic love poetry by making the woman who declaims the kharja literally «strip» for him, Ibn Ruhaym, using the same kharja, as indicated, flouts the tradition by picturing the woman declaiming the kharja as paying him a visit, and without previous notice:

Thumma 'ädat 'ațafat, hannat, fa-zārat bi-lā wa'di

'Then she became favourably disposed again, felt compassion, and paid (me) a visit without having promised to do so'

The present Section, however, is dealing with the way woman's-voice kharjas have little connection with the poems in which

${ }^{44}$ In muwashshah 4 (Ghazi, I: 420-422), explicitly addressed by the poet to his friend Ahmad, he says to his friend lovingly, yet defiantly (stanza 4) «If you are Joseph in your beauty, I am also unique in my poetic compositions, and many people would bear witness that I am ahead of (the poet) Labid in my poetic achievement».

45 It is no doubt open to question, as Ihsan Abbas suggests, although in a totally different context, as to whether the poets in such cases might have used the woman's-voice kharjas in order to leave a vague impression at the end of their muwashshah as to the true nature of their sentiments. (See Abbas' comments, 1987: 66 on what he calls the hāalat mubhama, 'the vague or ambiguous cases', in relation to the love stories narrated by Ibn Hazm in Tawq al-Hamäma). 
they appear. Ibn Ruhyam's muwashshah is a most striking, yet worthy witness in this respect. The first three stanzas in it are, so to speak, sung on the altar of the classical poetic tradition. In the first stanza he begs the copiously falling rain, in pre-Islamic or jāhili style, not to miss watering the abode of the beloved that he knew so well, at the edge of the sand dunes, siqt. In the second stanza the ardour of his passion, wajd, is getting the better of him; and in the third stanza, again in classical style, the remoteness of the beloved and the unrequited love have simply left him wasting away, and bringing him to grief, danā.

But the poet's fortunes seem totally transformed in the fourth and fifth stanzas, and all his anguish seems suddenly far behind him. The remote woman of pre-Islamic poetry whose love is only a fond and harrowing remembrance, is suddenly replaced by the figure of the slave girl in Abbasid libertine poetry, and particularly the poetry of that master of zarf in Arabic literature, Abū Nuwās. In stanza 4, the poet is suddently voicing his admiration for a buxom young girl, with full haunches, and a stylishly slanting belt she is wearing, who visits him, as already indicated, without previous notice:

Kä'ibun mā'ilatu 'l-zunnāri, muf'amatu 'l-ridfi

This young maiden, sporting a stylish belt, mä'ilatu 'l-zunnär, is reminiscent of mukhtasaru 'l-zunnār 'the youth with a short belt' (i.e. with the shapely waist) who serves Abū Nuwās his wine, more than three centuries before in Abbasid Baghdad (Diwān: 181).

Ibn Ruhaym's muwashshah is an extraordinary case of a muwashshah with two stanzas introducing the kharja. It introduces at the same time a manifest dichotomy between the pining love in the first three stanzas, and the self-indulgent and wanton love in the last two stanzas. For the purposes of a literary convention of introducing an element of zarf at the end of their poems, both Ibn Baqi and Ibn Ruhaym «abuse» the slave woman declaiming the kharja.

García Gómez is the only scholar, as far as I know, who has commented on the anomaly in Ibn Ruhaym's muwashshah, or on what can be described as the sudden change of fortune in the poet's love life in the course of his muwashshah. García Gómez (1975: 241) says:

«La estrofa 5 (que introduce la jarcha) demostraría que el amante no es tan desgraciado como antes ha dicho, puesto que pinta una escena erotica de atrevi- 
dos colores en la que la amada se queja de la 'indelicadeza' (tópico) de su enamorado».

One remark on the two muwashshahs by Ibn Baqi and Ibn Ruhaym referred to above seems imperative here. While the main parts of the strophes in them, the aghșan, move with distinctive ease and melodiousness, the $a q f \bar{a} l$ in them by contrast, read strenuously laboured, and with little good sense, let alone reading poetic or lyrical. It is no wonder that both poets avoided the added strain of providing a mațla' for their respective muwashshahs. ${ }^{46}$

\section{Woman's-voice Kharjas in Arabic:}

They too Run Counter to the Tradition of Arabic Poetry, and Read Like Addenda at the End of Poems

This study set out to tell the story of the muwashshahät and the kharjas, as it is told by the texts. As the texts have more woman's-voice kharjas in Arabic than in Romance, two or three of these should be examined here for the conclusion of the present discussion.

In his muwashshah no. 8 (Jaysh: 109-110, and Ghazi, I: 62-64) the poet al-Kumayt introduces an Arabic woman's-voice kharja with a blatantly impudent tone, which is shared by a good number of other similar kharjas. In the first three stanzas of his muwashshah he makes a determined effort to give a description of nature and blossom-time in Spring, but the picture he gives remains patchy, uninspired and incoherent. The fourth stanza of the muwashshah introduces the bacchic or carousing scene in a manner which sheds light both on the

${ }^{46}$ It is hardly necessary to remind readers that while the poets found relatively little strain when composing the aghșän inasmuch as they used a different rhyming scheme for them in each strophe, it was quite a Sisyphean struggle to maintain the same metrical and rhyming scheme in the matla' and the kharja and the rest of the aqfäl. But having said that, it is hardly necessary to remind readers also that the Sisyphean struggle, at the time when the muwashshahät started to be written, was part of the literary exercise and a distinctive trend in the regnant literary culture of the day. Hence the attempts made by mediocre poets or poetasters at the time to introduce eightfold or even tenfold-rhyming asmät into their muwashshahs. Likewise, introducing a kharja in Romance into a composition in classical Arabic, entailed great difficulty, and was, accordingly, considered a sure proof of superior merit. 
muwashshahāt and their kharjas. It merits quoting here if only in part, before reproducing the fifth stanza with the kharja:

$$
\begin{aligned}
& \text { Fa-'ghtanim mā qad șafã mina 'l-zamān wa-khla'i 'l-'udhrā } \\
& \text { Wa-'shrabi 'l-räha 'alā sam 'i 'l-qiyān mazzatan safrā } 47 \\
& \text { 'Take advantage of the good times which come your way, and throw } \\
& \text { away all restraint; and drink the pleasantly sharp wine, yellowish pale } \\
& \text { in colour, when enjoying the song and music of singing slave girls.' }
\end{aligned}
$$

It is hardly necessary to repeat that singing slave girls, the qiyān, were the mainstay of entertainment and diversion in al-Andalus with their $\operatorname{sam} \bar{a}^{\prime}$, their song and whatever musical performance went with it, as they had been both under the Umayyads and the Abbasids in the Arab East. Hence the saying that the major lexicons provide us with, bäta fi lahwin wa-sama a' 'He passed the night in the enjoyment of diversion, and singing and music' (Lane: art. sami 'a).

It would be noticed, however, that al-Kumayt, for obvious metrical exigencies, uses the term sam ' instead of the lexical sama $\bar{a}^{\prime}$. Nor is this the only licence the poet allows himself within the space of the two verses quoted. The standard idiomatic usage in Arabic for 'throwing off all restraint' is khal ' al-'idhär, literally 'removing the cheekpiece (of a horse's harness)'. The poet, as can be seen, uses the plural of 'idhär, which is 'udhur. But, as a further added licence, he, like all other muwashshah composers, eliminates, for both metrical and rhyme purposes, the medial vowel of 'udhur, and turns it to ' $u d h r$. But in this case at least, al-Kumayt and all other muwashshah composers are in good company. Abū Nuwās, long before them, had resorted to the same licence. He also on occasion uses ' $u d h r$ in place of 'idhār in his classical verses (e.g. Dīwān: 371 and 572). One legitimate license al-Kumayt resorts to is the shortening, qaș $r$, of the long alif in $s a f r a \bar{a}$. The shortened form, safrä, provides the requisite rhyme with 'udhrā.

It is in the light of such licence that Ihsan Abbas (1963, p. dhāl) speaks of «the muwashshah composers not being particular in their use of language as the poets are». But Abbas makes this statement while pointing out sheer grammatical solecisms in the traditional verses of al-A'mā al-Tuțīlī, whose knowledge of Arabic and Arabic

${ }^{47}$ It might be a printing mistake, but Jones reads murratan instead of mazzatan in his edition of Jaysh al-Tawshị. 
literature was little less than supreme. The muwashshahät, it would be readily agreed, have some of the most complex rhyme patterns of any literature, and the remark has quite rightly been made about «complex rhyme-patterns, and the involved modes of expression which they entail» (Press: 105). Apart from that, al-Andalus, where the muwashshahät were being written, lacked the directing and predominant authority of a central court at home, and felt far removed and free from the hegemony of any such courts in the Arab East. The literati in al-Andalus could afford to lower their guard.

Al-Kumayt's muwashshah (no. 8), as already pointed out, has three stanzas descriptive of nature, followed by a fourth with a bacchic or wine theme. The amenable natural surroundings of the first three stanzas constitute an inducement for the carousing scene in the fourth. The fifth stanza and kharja which follow, however, have no thematic or syntactic link with what precedes them:

\begin{tabular}{|c|c|}
\hline Wa-fatātin fatanat bi-ḥusnihā & wa-tathanni-hã \\
\hline Tashtakī țūla jafä'i khidni-hā & hinna $y u^{\prime} d h \overline{-}-h \bar{a}$ \\
\hline Wa-tughannì bi-raqīi lahni-hā & wa-aghāni-hā \\
\hline $\begin{array}{l}\text { Dhubtu wa-'llähi asan nutliq șiyāh } \\
\text { Wa-'amal lī fí shufayfät-ī jirâh }\end{array}$ & $\begin{array}{l}\text { qad kasar nahd-ī } \\
\text { wa-nathar 'iad-i }\end{array}$ \\
\hline
\end{tabular}

'And a young maiden, enticing with her beauty and her swinging gait, Complains of the coarse treatment of her companion, intent on hurting her, And who (yet) sings her pert and jaunty song:

«By God, I cannot take more of this suffering, he has bruised my breast, Left bleeding cuts on my lips, and scattered the beads of my necklace»'

If there is any one striking feature about al-Kumayt's muwashshah, however, it is the way that its kharja, or the whole of the fifth stanza which introduces the kharja reads like an afterthought, with little or no connection with the rest of the muwashshah. If that fifth stanza with the attached kharja were to be found on a separate folio of a manuscript that had become badly unbound, the only clue which would relate it to al-Kumayt's muwashshah is simply its metrical and rhyming schemes. This is more or less true of the large majority of full-fledged woman's-voice kharjas in Arabic or in Romance.

The muwashshahät, it must be remarked, were an experimental genre in Andalusi Arabic literature, and continued to be an experimental undertaking until they were turned into regular stanzaic 
qasidas by literati like Ibn al-Khați (d.1374) and Ibn Zamrak (d. after 1393) in Nasrid Granada.

While muwashshah no. 8 by al-Kumayt was a rather jejune essay to describe nature, leading to a brief bacchic scene, muwashshah 10 by al-Jazzār (Jaysh: 192-194 and Ghazi, I: 100-102) is focused throughout, and rather in classical style, on the poet's tribulations and little requital in love. The poet warns at the outset anyone free of love, ya man yabitu khaliyya 'l-qalbi, to desist totally from blaming him, because one of those divinely slender women, who flaunt bracelets on their arms, had left him without his mind and his senses ... $f a-b i \overline{m i n}$ dhawāti 'l-qulbi, hayfä'u qad salabat-nī lubb-i $\bar{l}^{48}$.

Stanza 5 introducing the kharja in al-Jazzār's muwashshah has nothing to do with the poet or his tribulations in love. It is a totally separate and different story of love, and with (its own) different protagonists:

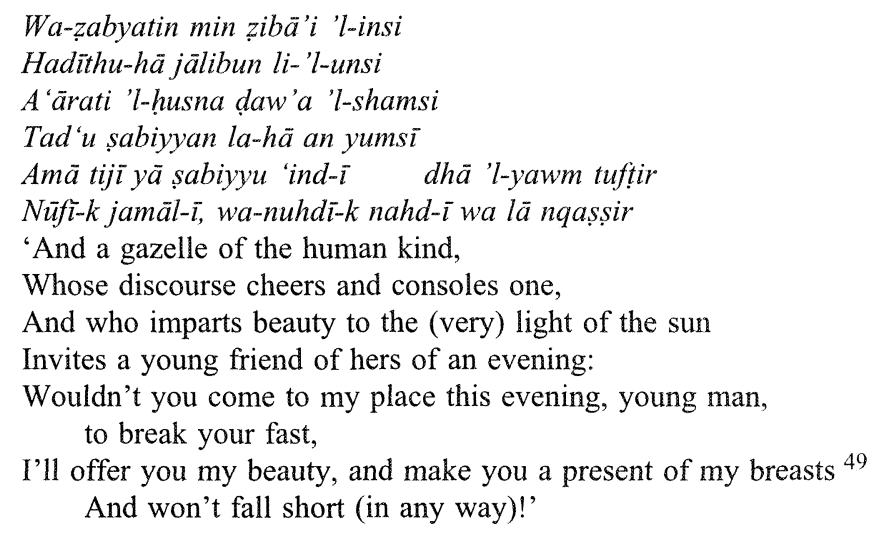

Al-A 'mā al-Tutịli is perhaps the one poet in the history of the Arabic muwashshahät who introduces Romance kharjas into his poems, and makes Romance and Arabic sound like natural cohabitants. But our present concern is with woman's-voice kharjas in Arabic, and in this field too he is nothing less than an adept. The kharja I am

${ }^{48}$ Readers should not miss noting that perfect facet of $\mathrm{badi}^{-}$(never lacking in the muwashshahāt), the near-total paronomasia between $q a l b-\bar{l}$ ' $m y$ heart' and qulbi 'bracelets', in the verses above.

49 Readers will note that for both metrical and rhyme exigencies the poet uses the singular in Arabic, 'breast', instead of 'breasts'. 
quoting here by this 'skin stuffed with knowledge' appears abruptly, as usual in such cases in the poet's muwashshah no. 14 (Ghazi I: 285-287 and Jaysh: 45-47). This is a poem with a wine overture (matla), a brief description of Spring (stanza 1), one stanza referring to the love of a male friend (no. 2), another paying tribute to the poet's boon companions (no. 3) and a fourth in praise of a noble benefactor. None of these, however, have any apparent or intrinsic link with the fifth stanza which introduces the kharja, and which is reproduced here:

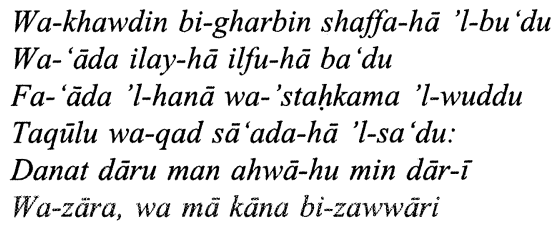

'And a beautiful young maiden in Algarve, rendered lean by living far away (from her companion), had her companion return after his absence, and she felt again assured of happiness and affection. So she said, overjoyed by her good turn of fortune: «The house of the one I love is now close to my house, and he pays (me) visits, although he never went out on visits before»'.

This kharja by al-A 'mā al-Tuṭilī might well seem inconsequential, except for two relevant remarks which should not be overlooked, or even relegated to footnotes. The first concerns the incertitude of the texts, both of the muwashshahät and their kharjas, which have come down to us. The women declaiming the kharjas in Arabic or Romance are of little consequence in themselves, as has already been remarked above. Who they are, or whether they have a known abode are not matters of relevance. They are «extras» in the make-up of the muwashshahs, whose role is to hype up these poems, and particularly by brazen or brash declamations or behaviour attributed to them. It comes as a surprise that al-A 'mā al-Tutịlì tells us that the woman declaiming the kharja in this case lived in the Algarve. It reads both modern and gallant on the part of the poet, that he should supply the added information. But the texts nowhere say clearly or unambiguously bi-gharbin, i.e. 'in the Algarve'. Ghazi (I, 287) reads "wa-khawdin bi-gharbin...", and says in a footnote that the original manuscript text reads: 'urb, in place of bi-gharbin. Jones (Jaysh, 47) points out in a footnote that the original text reads $l i$ - 'arb, and that he 
has amended this to read la' $\bar{u} b$. Abbas (1963: p. $d \bar{a} d$ ) reads wa-khawdu 'urbin 'a young Arab maiden', and he goes on to draw diverse conclusions from this tentative reading. He says: "The poet, it seems, had a preference for kharjas in classical Arabic, so he resorts to the artifice of making an Arab young woman sing [sic] the kharja ... for if the young woman is Arab, it is only natural that he would have to abide by (the rules of) $i$ ' $r a \bar{b} b$ in the kharja».

I have not backed away from giving all this detail, in order to give the warning that if the bungled transcript of one Arabic term can lead to so many diverse readings and conclusions, the texts of the Romance kharjas should be approached with the utmost caution and humility.

The remaining remark to be made on al-A'mā al-Tuțīil's kharja is concerned with its likely provenance or original inspiration. Although absolute certainty is impossible in such cases, there is every likelihood that al-A'mā was paraphrasing in his kharja a well-known verse by the early Islamic poet al-Aḥwaṣ al-Anșārī (d. 728):

\footnotetext{
Wa-mā kuntu zawwāran wa-lākinna dhā 'l-hawā Idhã lam yazur, ${ }^{50}$ là budda an sa-yazūru

'I was never one to go paying visits, but for someone who is in love visiting will become as sure as fate'.
}

\section{Ibn Sanā' al-Mulk and the Kharjas}

In any study group or conference dealing with the muwashshahāt and the kharjas (but not the zajal, of course), the most common statements which keep being heard are: «Ibn Sanā' al-Mulk says ...» or «Ibn Sanā' al-Mulk tells us...». I strongly feel that it is time we stopped doing this for two reasons. The first is that, since he does not mention any sources, Ibn Sanā' al-Mulk seems to have drawn his conclusions, as we have to do, from the available texts. The second reason is that Ibn Sanā' al-Mulk's reaction to the kharja in particular was a psychological reaction, and not a considered literary evaluation. These two assertions will be discussed in succession in what follows.

${ }^{50}$ Noeldeke (24) reads in lam yazur, which is consistent, of course, with the sardonic charge implied in the verse. Anyone tempted to read in lam yuzar should remember that women, in the tradition of Arabic love poetry, did not visit a man in love with them. 
Ibn Sanā' al-Mulk, although some eight centuries ahead of us in point of time, was in the same boat with us inasmuch as he, like us, had to draw his conclusions about the muwashshahät and their kharjas from the texts available to him. At the time he wrote (some 150 years after the appearance of the first muwashshahs), and being far removed from al-Andalus, as he was, he could not be a preceptista writing a normative treatise on the muwashshah genre and its multifarious kharjas.

Ibn Sanā' al-Mulk, no doubt, provides in his Dār al-țirāz a competent descriptive treatise of the muwashshahät, and what he writes, as Stern (1974: 6) aptly puts it, is «always instructive». But there is no denying that this ardent aficionado of the muwashshah genre was a brilliant publicist. By giving his treatise the subtitle $f^{i}$ 'amal almuwashshahät 'On the manner of composing muwashshahs', and by using such terms in his comments on the kharja like wa-'l-shartu $f i-h \bar{a}$ 'it is stipulated in it', and $w a-' l-m a f r u \bar{d} u f i-h \bar{a}$ 'it is premised in it', etc. (Rikabi: 40-41), he gave his readers the impression that he was writing a prescriptive normative work, or an ars poetica for those intent on writing muwashshahs. ${ }^{51}$

Ibn Sanā' al-Mulk treats the kharja like an isolated spectacular phenomenon which appears at the end of muwashshahs. In only one isolated instance in his work (Rikabi: 40) he applies the epithet quzmanniyya to the kharja to point out that its language can be ungrammatical like the language of Ibn Quzmān in his zajals. But Ibn Sanā' al-Mulk nowhere in his work mentions the zajal as a popular genre which developed side by side with the muwashshah in al-Andalus. As a result, he is unable to relate the kharja with its «wanton disregard» of grammatical rules, and its equal «disregard» of the rules of social decorum and decency to any contemporary literary

51 All this, it would seem, must have led the editor of Dār al-tirāz (Rikabi: 13) to speak of Ibn Sanā' al-Mulk as «undertaking the task of laying down the rules for this poetic art [the muwashshah], pointing out its characteristics, the ways of composing it and the poetic metres (involved in that).» Rikabi indeed goes on to say (13) that Ibn Sanā' al-Mulk was thus «the first poet to lay down the rules of composition for the $m u$ washshah genre both in the Arab East and in the Maghreb». Many of us approach Dār al-țiräz with the attitude which Rikabi seems to have readily espoused, and perhaps helped to perpetuate. Stern (1974: 5), like Rikabi, speaks of «the rules laid down by Ibn Sanā' al-Mulk» for the muwashshah, although he qualifies these rules as being "somewhat incomplete and sometimes slightly scholastic» or (1974:39) as «somewhat schematic ...) whatever he might have meant by these qualifications. 
phenomenon which endows it with a parentage, other than being a literary «foundling», among a whole line of other sister «foundlings». If Ibn Sanā' al-Mulk had known the zajal, or studied it with the same zeal as he studied the muwashshahät, he would have been able to define the kharja perhaps as a zajal or cejelesque element at the end of the «highbrow» classical Arabic muwashshah.

One, of course, should not fail to add that there were other widespread literary developments in al-Andalus of which Ibn Sanā' al-Mulk shows no awareness at all. In the thirteenth century Ibn 'Abd al-Malik al-Marrākushī describes Ibn Quzmān as al-adīb al-shahīr 'l-ijäda fi 'l-nazm al-hazlī... 'The man of letters widely renowned for his excellent poetic compositions in the hazli or burlesque style ...' (Abu-Haidar, 2001: 38). Long before that, (in all likelihood before Ibn Sanā' al-Mulk was born), Ibn Quzmān himself, in one clear instance at least (zajal 65, last strophe), classifies his popular zajals as part of the hazl literature prevalent in al-Andalus in his day (Abu-Haidar 2001, Chapters Two and Five). If Ibn Sanā' al-Mulk had been aware of this hazl or hazli literature in al-Andalus, he could well have classified the kharja as an element of hazl or burlesque in the usually staid muwashshah. Much better still, he could have given the kharja the prestigious and respectable parentage of being an element of zarf at the end of the muwashshah. The line of distinction between hazl and zarf is a tenuous one. Only the latter has added associations with gentlemen and with refined manners, and with sharp verbal effects which do not necessarily involve coarse jesting and obscenity.

In a similar, yet more puzzling way, Ibn Sanā' al-Mulk seems so much carried away by the phenomenon of the kharja in Andalusi literature to be unable to relate it to analogous, if not virtually identical, literary developments nearer home to him in the Arab East. In one solitary instance in Dār al-Tirāz (Rikabi: 40) he says that it is stipulated in the kharja (Ar. wa-'l-shartu fi-hā) that it be hajjajjiyya as far as the use of bold and indecent language, sukhf, is concerned. This, of course, is a reference to the poetry of al-Husayn Ibn al-Hajjajj of Baghdad (d. 1000), characterized by its obscene or scatological language. But Ibn al-Hajjāj's poetry, like the kharja of the muwashshah in al-Andalus, was not without an ancestry or parentage. Ibn al-Hajjāj in the tenth century, it might well be said, was the proud progeny of the mujūn poetry on which poets like Wāliba ibn al-Hubāb and Abū Nuwās in the eighth century had conferred both status and popularity. 
Ibn Sanā' al-Mulk could well have described the kharja as an element of mujūn, of «spice» and piquancy at the end of the muwashshahs.

Before I move on to my second reason for questioning the credentials of Ibn Sanā' al-Mulk as a theorist on the muwashshahāt and the kharjas, I should give my readers at least one simple and clear example of his purely descriptive, rather than analytic and inductive approach.

Ibn Sanā' al-Mulk tells his readers (Rikabi: 32) that the large majority of the muwashshahät (those compositions he describes as tämm 'complete') start with a matla' (loosely translated at times as 'prelude'), while a good many among them, the acephalous ${ }^{52}$ lot (Ar. aqra) start without a matla'. (He in fact, refers to the verses with common rhymes in the strophe, the asmät, as aqfäl, and refers to the matla', accordingly, as a qufl. While the majority of the muwashshahät, he says, start with the qufl, the acephalous or bald lot among them start with the bayt, by which he denotes the part of the strophe with independent rhymes. See Stern, 1974: 13 and 15, n. 8).

No one would question the accuracy of the above statement by Ibn Sanā' al-Mulk, although the terminology he uses for the various parts of the strophe is awkward and questionable. ${ }^{33}$ But leaving the termi-

52 The term «acephalous» is justified in view of the fact that $r a$ ' $s$ is occasionally used as the equivalent of mattla 'in the Diwän of Ibn al- 'Arabī, although the renowned Sufi is a relatively late composer of muwashshahs.

53 It is rather curious that all the technical terms used in the composition of the $m u$ washshah, including, of course, the term muwashshah itself (Abu-Haidar, 2001: 124), are clearly indicative of their significations, and the purpose they serve, except the terms qufl, aqfäl used by Ibn Sanā' al-Mulk to denote the asmät lines of common rhyme, and, of course also, the matla'. Qufl, aqfäl, literally 'lock', 'locks', do not seem to have any plausible semantic sanction as a reference to lines or verses with common rhymes, and even much less so to 'opening verses' or a matla'. We can allow ourselves to interpret the term qufl with some latitude, as a reference to lines which 'end' or, so to speak, act as a 'seal', setting the limit of each strophe. We can then go on to describe the kharja as Ibn Sanā' al-Mulk does (Rikabi: 40), as al-qufl al-akhï mina 'l-muwashshah 'the last stanza seal in the muwashshah'. But such an interpretation of qufl completely founders when the term is applied to the mațla', the opening verses, and when Ibn Sanā' al-Mulk says (Rikabi: 32 ) that «the muwashshah tāmm starts with the aqfäl». Ibn Sanā' al-Mulk does not anywhere mention his sources. Mattla', sanctified by usage in the classical qasida, should continue to «reign supreme», and apply as well to the opening couplets of the muwashshah. But instead of reading qufl, we should perhaps read qafl (nomen unitatis: qafla) implying a return or 'awda, at the end of each strophe to the metre and common rhymes of the matla', or in the absence of one, to the rhyme scheme of the first qafla or qaflät. I suggest reading qaflät following the precedent set by Ibn Quzmān who reads kharjāt, and not kharajät (zajal 46, str. 6). This is at least one way in which Ibn Sanā' al-Mulk's term 
nology aside, one is tempted to ask if it was simply optional to start a muwashshah with or without a matla: Was the choice, in other words, totally dependent on the individual preferences or individual whims of the poets? And what, if anything at all, prompted or decided the choice one way or the other? Ibn Sanā' al-Mulk is of course quiet about any such questions. Was the matla' also of a second-rate or middling importance in the muwashshah in view of the highly unequable attention which Ibn Sanā' al-Mulk gives to the kharja? After all, muwashshahs without a kharja are not known, while muwashshahs without a matla' are many. ${ }^{54}$

There is a simple reality about the omission of the matla ' of which Ibn Sanā' al-Mulk, a composer of muwashshahs himself, would and should have been fully aware. As it was an inescapable necessity that the matla' should be in the same metre, and reproduce the rhyming scheme of the rest of the asmät, some poets must have found it expedient, or even a heaven-sent opportunity at times, to lighten their burden at the outset, and get out of the obligation of writing a matla: The matla' was an item they could jettison with impunity. In that way they wrote only five sets of asmät with common rhymes instead of the normally requisite six. If Ibn Sanā' al-Mulk was writing the ars poetica of the muwashshah, he does not anywhere tell his readers if there was any other reason for omitting the matla' apart from sheer convenience.

The matla ' had a distinctive aura about it in classical Arabic poetry, and there is no reason to believe that it was less momentous in the muwashshah. Individual muwashshahs were known and identified by their matla', and only in the absence of one, by the line which followed in the first strophe. Although Ibn Bassām refers to the kharja by the noteworthy term markaz 'base', 'point d'appui', 55 and Ibn Sanā' al-Mulk confers on it the equally notable description, al-asās 'the foundation', no muwashshah has ever been identified by its kharja. There are cases of poets who have made their mark by single

qufl could be accommodated as a meaningful technical term within the schema of the $m u$ washshah.

54 Jones (24) says that "Aqra 'poems make up almost one sixth of the extant corpus», while James Monroe (1992: 405) says that «About one-third of the extant Andalusi muwashshahs lack the initial refrain»r.

${ }_{55}$ Did Ibn Bassām, one wonders, approve of the reference to the kharja as al-markaz simply because it appears at the bottom end of the muwashshah? 
memorable opening verses or mațla's, but not by any kharja or collection of kharjas. ${ }^{56}$

Neither Ibn Bassām nor Ibn Sanā' al-Mulk, in what they have to say about the muwashshah, come across to us as discriminating critics of poetry. Ibn Bassām, of course, says that he had no time for poetry in any form, in what amounts to a candid confession at the outset in his renowned al-Dhakhīra (Abu-Haidar, 2001: 125, n. 1). Ibn Sanā' al-Mulk was more committed. The selection he makes of muwashshahs in Dār al-Tiräz and the structural analysis he makes of his selections are worthy of our commendation and our gratitude. What mars his interest and his great industry, however, is that he was too much carried away by his zeal for the kharja. I first made the remark that Ibn Sanā' al-Mulk «is clearly carried away by his enthusiasm» for the kharja back in 1975 (202), and I pointed that out again in 1978 (8), but kept being troubled by the feeling that my readers might have thought that I was using the terms "carried away» as a cosseting or indulging form of appreciation, when in fact I meant them as an unqualified critical stricture.

I do not make any novel revelation if I repeat the well-known dictum that what we do is of much greater significance than what we say, or that our deeds constitute a more valid testimony about us than our words. This study started as an attempt to understand the muwashshahāt and the kharjas through an examination of the available texts, and not an examination or a study of what has been said about them. If I say that Ibn Sanā' al-Mulk's driving enthusiasm for the kharja blinded him to many of the fine points of both kharja and muwashshah, I am, likewise, judging him by the muwashshahs he wrote and their kharjas, and not by what he had to say or even stipu-

\footnotetext{
56 In the famous story often quoted from al-Muqtataf of Ibn Sa'īd when washshähs of calibre met at one time in Seville to read some of their compositions, it was upon hearing a most brief mațla ' by al-A'mā al-Tuțīī, and not a kharja, that Ibn Baqī and the rest of those poets present tore up, with a sense of shame, what they had prepared for the occasion (al-Muqtataf, 1984: 256, and Ghazi, I: 247-248, n. 2). The claim to fame as a washshạ h of the renowned man of letters and historian, Ibn al-Khatīib, rests primarily on the matla' of a muwashshah he wrote expressing nostalgia for al-Andalus while he was an exile from it:

Jāda-ka 'l-ghaythu idhā 'l-gaythu hamā

Yã zamāna 'l-wașli fì 'l-Andalusi...

'May the rain-clouds generously water those haunts,

Where reunion was once vouchsafed for us in al-Andalus'
} 
late as conditions (Ar. shurüt) when he was studying the compositions of others.

Ibn Sanā' al-Mulk, as we all know, has left us in the Second Part of his Dār al-Tiräz thirty-five muwashshahs of his own composition. For those who care to read them, and not restrict their reading to his theoretical comments in the First Part, it would be plain that his understanding and treatment of the kharja in his own compositions are those of an adolescent who finds in the kharja a means of escape or liberation from emotional inhibitions. In practically every one of his muwashshahs, the kharja amounts either to an insinuation about a bedroom scene, or an invitation to one. Ibn Sanā' al-Mulk very much represents in his muwashshahs the zarf of the kharja gone awry. His kharjas represent that zarf which, in Maxim Gorky's words, makes the focus of wit or wittiness the very mystery through which people everywhere are born. In plain terms Ibn Sanä' al-Mulk, like many of the poets whose works were examined in Parts II and III, treats the kharja like a decree of absolution or of licensed licentiousness, an extremity it was not originally intended for.

The remark has been made that wine among the revellers and poets of Islamic Spain «gave a double liberation because it was forbidden» (Brenan: 50). But the muwashshahāt, like the mujūn poetry which preceded them in the Arab East, belie such a simplistic statement. Wine was readily available to the poets in al-Andalus and elsewhere, and the ever-present wine overtures and wine themes in the muwashshahät and the contemporary zajal attest to that. The kharja, however, did represent a liberation if it flouted the social mores, and trifled with the strict demands or the purity of literary Arabic. The kharja, as we know, could not only be couched in a low-level popular Arabic, but it could also be peppered or «spiked» with Romance, or even be wholly in Romance (especially in the early experimental stages in the development of the muwashshah).

But for the record, this article should not be ended without drawing attention to a simple fact about the muwashshahät which should not be overlooked or lost sight of whenever they or their kharjas are discussed or studied. In the best poems among them, or in the purest or nearest compositions among them to a "pure poem», the matla", the aghșān, the asmāt and the kharja, all those jerky trappings, become indistinguishable in a single unity or entity which is the poem. For examples of such «pure poems» pride of place should go to Ibn 
Zuhr's Ayyuhā 'l-sāqī ilay-ka 'l-mushtakā (Ghazi II: 76-78), ${ }^{57}$ and not far behind Ibn Sahl's Hal-darā zabyu 'l-himā an qad hamā (Ghazi, II: 182-185). The first, perhaps one of the most perfect and melodious poems in Arabic poetry of all time, has no kharja, even remotely, answering to the descriptions of Ibn Sanā' al-Mulk or the way he would have the kharja.

The wit and brilliance at every stage of Ibn Sahl's muwashshah, likewise, make the kharjas as described, or turned to use by Ibn Sanā' al-Mulk, seem little more than trivia. As in Ibn Zuhr's muwashshah too, the technical terms seem out of place. There is many a qufl (to use Ibn Sanā' al-Mulk's term) in Ibn Sahl's muwashshạ which could serve, and with distinction, as its kharja. Its matla ' was borrowed by Ibn al-Khatib and used as the kharja of his single most famous muwashshah referred to above.

It remains to add that the ease and melodiousness, as well as the charm which characterize al-A'mā al-Tuṭilī's muwashshaḥs are not bestowed on them either by their Arabic or their Romance kharjas. For such considerations, Ibn Sanā' al-Mulk could have stopped at some stage to qualify his heady exhilaration concerning the kharja.

In the last analysis, Ibn Sanā' al-Mulk was an aficionado of the $k h a r j a$, and not an aficionado of the muwashshah.

\section{References}

Abbas, I. (ed.) (1987), Rasā'il Ibn Hazm al-Andalusī, Part I, Beirut: Al-Mu'assasa al-'Arabiyya.

ABU-HAIDAR, J.A. (1975), A Study of Certain Linguistic, Metrical and Literary Aspects of the Diwān of Ibn Quzmān (d. 1160), unpublished $\mathrm{PhD}$ thesis, University of London.

- (1978), "The Kharja of the Muwashshah in a New Light", Journal of Arabic Literature, Vol. IX, 1-13.

- (2001), Hispano-Arabic Literature and the Early Provençal Lyrics, London: Curzon Press.

ABŪ Nuwās (1962), Dīwān, Beirut: Dār Șādir, Dār Bayrūt.

Al-AhwĀNī, 'A. (1957), Al-Zajal fì al-Andalus, Cairo: Mațba'at al-Risāla.

AL-A'MĀ AL-TUTî̄Lİ, Dīwān, Abbas, I. (ed.) (1963), Beirut: al-Maṭba'a al-Andalusiyya.

Bradley, A.C. (1909), Oxford Lectures on Poetry, London: Macmillan and Co. Ltd.

${ }^{57}$ I am qualifying Ibn Zuhr's poem with the terms «pure poem» used by A.C. Bradley (1909: 22) where he says that «the degree of purity attained may be tested by the degree in which we feel it hopeless to convey the effect of a poem or passage in any form but its own». 
Brenan, G. (1963), The Literature of the Spanish People, Harmondsworth: Penguin Books.

BRIFfaUlt, R. (1945), Les Troubadours et le sentiment Romanesque, Paris: Editions du Chêne.

- (1965), The Troubadours, Bloomington: Indiana University Press (translated from the French by the author and edited by L.F. Koons).

CACHIA, P. (1967), in W. Montgomery-Watt, A History of Islamic Spain, with additional sections on literature by P. Cachia, Edinburgh: Edinburgh University Press.

CORRIENTE, F. (1996), Ibn Quzmān: Cancionero Andalusi (translated with introduction), Madrid: Hiperión.

- (1997), A Dictionary of Andalusi Arabic, Leiden: Brill.

Deyermond, A. (1992), “The Romance Kharjas in Hebrew Script: Woman's Song or Man's Text?", in Benabu, I. (ed.), Proceedings of the Jerusalem Colloquium: Litterae Judaeorum in Terra Hispanica, Jerusalem: The Hebrew University of Jerusalem.

Frenk Alatorre, M. (1975), Las Jarchas Mozárabes, México: El Colegio de México.

GARCíA GómEZ, E. (1952), "Veinticuatro jarchas romances en muwashshahas árabes", Al-Andalus, 17, 57-127.

- (1965), Las jarchas romances de la serie árabe en su marco, Madrid: Sociedad de Estudios y Publicaciones.

- (1975), Las jarchas romances de la serie árabe en su marco, Madrid: Alianza Editorial.

GARULO, T. (1986), Dīwān de las poetisas de al-Andalus, Madrid: Hiperión.

- (1990), El Libro del brocado (Kitāb al-muwashshā of al-Washshā'), A Study, Translation and Indexes, Madrid: Alfaguara.

GHAZI, S. (1979), Dīwān al-Muwashshaḥāt al-Andalusiyya, 2 vols., Alexandria: Munsha'at al-Ma'ārif.

GiBB, H.A.R. (1963), Arabic Literature: An Introduction, Oxford: The Clarendon Press.

Gorky, M. (1923), My Apprenticeship, My Universities, Moscow: Progress Publishers.

IBN BASSÃM AL-SHANTARĨNĩ, Al-Dhakhira fì Maḥāsin Ahl al-Jazìra, 4 parts, 8 vols., Abbas, I. (ed.) (1978-1979), Beirut.

IBN BiShrĩ AL-GHARNĀṬī, 'Uddat al-Jalīs, JONES, A. (ed.) (1992), Cambridge,Trustees of the «E.J.W. Gibb Memorial». (referred to as 'Udda).

IBN DĀWûd AL-IșBAHĀNī, Kitāb Al-Zahra, Al-Sāmarrā'î, I. (ed.) (1985, $2^{\text {nd }}$ ed.), Vol. I, Al-Zarqā', Jordan: Maktabat al-Manār.

IBN AL-KHAṬīB, LISĀN AL-DİN, Jaysh al-Tawshịh, JONES, A. (ed.) (1997), Cambridge: Trustees of the «E.J.W. Gibb Memorial». (referred to as Jaysh).

IBN QUZMĀN, ABŪ BAKR, Le Divan d'Ibn Quzmān (facsimile ed. by Le Baron David de Gunzburg) (1896), Berlin: S. Calvary \& Co.

IBN RASHĪQ AL-QAYRAWĀNİ, Al- 'Umda fỉ Mahäsin al-Shi ' $r$, Qarqazan, M. (ed.) (1988), Beirut: Dār al-Ma'rifa.

IBN SA'ĪD AL-ANDALUSĪ, Al-Muqtațaf min Azāhir al-Ṭuraf, Hasanayn, S.A. (ed.) (1984), Cairo: Al-Hay'a al-Mișriyya al-'Āmma li-'l-Kitāb.

IBN SANĀ' AL-MULK, (1980, $3^{\text {rd }}$ ED.), Dār al-țirāz fì 'amal al-muwashshahạt, al-Rikabi, J. (ed.), Damascus: Dār al-Fikr.

Jones, A. (1988), Romance Kharjas in Andalusian Arabic Muwashshah Poetry, London: Ithaca Press.

AL-KHĀNJİ, M.A. (ed.) (1324 A.H.), Kitāb al-Muwashshā, Cairo: Maktabat al-Khānjī.

Monroe, J.T. (1992), "Zajal and Muwashshaha: Hispano-Arabic Poetry and the Romance Tradition", The Legacy of Muslim Spain, Jayyusi, S.K. (ed.), Leiden: Brill, 398-419.

Nicholson, R.A. (1956), A Literary History of the Arabs, Cambridge: Cambridge University Press. 
Noeldeke, Th. (1961), Delectus Veterum Carminum Arabicorum, Wiesbaden: Otto Harrassowitz.

PRESS, A.R. (1971), Anthology of Troubadour Lyric Poetry, Edinburgh: Edinburgh University Press.

AL-QAISI, F.A. (1991), Islamic Almería: Its Historical Background and its Arabic Literature during the $5^{\text {th }}$ A.H./1 $1^{\text {th }}$ Century A.D., unpublished $\mathrm{PhD}$ thesis, University of London.

RIBERA, J. (1928), Disertaciones y opúsculos, 2 vols., Madrid: Imprenta de Estanislao Maestre.

SCHOElER, G. (1991), "The Origins of the Poetic Forms of the Troubadours: The Liturgical and Arabic Theories", Poesía Estrófica, Corriente, F. and Sáenz-Badillos, A. (eds.), Madrid: Universidad Complutense, 325-335.

Sola-Solé, J.M. (1973), Corpus de poesía mozárabe, Barcelona: Ediciones Hispam.

STERN, S.M. (1950), "Muhammad ibn 'Ubāda al-Qazzāz, un andaluz autor de muwashshahas", Al-Andalus 15, 79-109.

- (1953), Les Chansons mozarabes, Les vers finaux (kharjas) en espagnol dans les muwashshahs arabes et Hébreux, Palermo: U. Manfredi (repr. 1964, Oxford: Bruno Cassirer).

- (1974), Harvey, L.P. (ed.), Hispano-Arabic Strophic Poetry, Oxford: The Clarendon Press.

YĀQúT AL-Hamawĩ, Mu'jam al-Udabā', 7 vols., Abbas, I. (ed.) (1993), Beirut: Dār al-Gharb al-Islāmī.

ZWARTJES, O. (1997), Love Songs from Al-Andalus, History, Structure and Meaning of the Kharja, Leiden: Brill.

\section{RESUMEN}

Se ha dicho que para entender una literatura lo mejor es leer sus obras, y no lo que sobre ella se ha dicho o escrito. Este artículo, en cuatro partes, es un intento de estudiar las muwashshahät y sus kharjas, basado solamente, dentro de lo posible, en los textos con los que contamos. El artículo llega a tres conclusiones, no del todo nuevas para mis lectores:

1. Si bien las muwashshahăt fueron producto de la tradición literaria clásica árabe, su desarrollo se enlaza inevitablemente con factores específicos, políticos y sociales, del medio andalusí.

2. La kharja es una salida de 'ingenio' o 'ingeniosa', zarf o hazl, al final de la muwashshah. Sea cual fuere su propósito de haber existido antes de las muwashshahăt, las kharjas de voz femenina en lengua romance, al igual que sus equivalentes árabes, tenían como función suministrar el mismo requisito de zarf al final de la muwashshah.

3. La reacción de Ibn Sanā' al-Mulk hacia la kharja fue en gran medida una reacción psicológica, y no una respuesta literaria bien ponderada. La mejor manera de saber lo que Ibn Sanā' al-Mulk pensaba de las muwashshahät es leer las que él mismo compuso, y no lo que opinó sobre la kharja. 


\begin{abstract}
The best way for understanding any literature, we are told, is by reading the literature itself, and not what has been said or written about it. This article, in four parts, is an attempt to study the muwashshahät and their kharjas depending, as far as possible, solely on the available texts. It arrives at three conclusions not altogether new to my readers:

1. The muwashshahāt were the product of the classical Arabic literary tradition, but their development is, inevitably, linked with specific political and social factors in the Andalusi milieu.

2. The kharja is a sally of zarf or hazl 'wit', 'wittiness' at the end of the muwashshah. Woman's-voice kharjas in Romance, whatever the purpose they served, if they existed prior to the muwashshahät, were, like their Arabic counterparts, meant to provide the same zarf requirement at the end of the muwashshah.

3. Ibn Sanā' al-Mulk's reaction to the kharja was largely a psychological reaction, and not a considered literary one. The best way of knowing what Ibn Sanā' al-Mulk thought of the muwashshahät is by reading the muwashshahs he wrote, and not what he had to say about the kharja.
\end{abstract}

